NBER WORKING PAPER SERIES

\title{
DO COLLATERAL SANCTIONS WORK? EVIDENCE FROM THE IRS' PASSPORT CERTIFICATION AND REVOCATION PROCESS
}

\author{
Paul R. Organ \\ Alex Ruda \\ Joel Slemrod \\ Alex Turk \\ Working Paper 29029 \\ http://www.nber.org/papers/w29029
NATIONAL BUREAU OF ECONOMIC RESEARCH
1050 Massachusetts Avenue
Cambridge, MA 02138
July 2021

We thank Nick Gebbia, Tatiana Homonoff, Jeff Hoopes, Jan Millard, Stacy Orlett, and participants at the 2020 National Tax Association annual conference, the 2021 IRS/TPC Joint Research Conference on Tax Administration, and University of Michigan seminars for helpful comments. All data work for this project involving confidential taxpayer information was done on IRS computers by IRS employees, and at no time was confidential taxpayer data ever outside of the IRS computing environment. Organ is a student volunteer with the IRS through the Joint Statistical Research Program. Slemrod is an IRS employee under an agreement made possible by the Intragovernmental Personnel Act of 1970 (5 U.S.C. 3371-3376). The views and opinions presented in this paper reflect those of the authors. They do not necessarily reflect the views or the official position of the Internal Revenue Service or the National Bureau of Economic Research. All results have been reviewed to ensure that no confidential information is disclosed.

NBER working papers are circulated for discussion and comment purposes. They have not been peerreviewed or been subject to the review by the NBER Board of Directors that accompanies official NBER publications.

(C) 2021 by Paul R. Organ, Alex Ruda, Joel Slemrod, and Alex Turk. All rights reserved. Short sections of text, not to exceed two paragraphs, may be quoted without explicit permission provided that full credit, including $\odot$ notice, is given to the source. 
Do Collateral Sanctions Work? Evidence from the IRS' Passport Certification and Revocation Process

Paul R. Organ, Alex Ruda, Joel Slemrod, and Alex Turk

NBER Working Paper No. 29029

July 2021

JEL No. H2,H24,H26

\section{ABSTRACT}

Penalties for tax evasion are typically financial, but many jurisdictions also utilize collateral sanctions that deny access to some government-provided service. To learn about the effectiveness of such penalties, we examine a U.S. policy restricting passport access for taxpayers with substantial tax debt, known as "certification." We find an immediate and strong positive effect on compliance actions when a passport request is denied. We then take advantage of randomization during the policy rollout to identify the direct compliance effect of certification, and find smaller but non-trivial effects whose heterogeneity is consistent with measures of taxpayers' value of having a passport.

Paul R. Organ

University of Michigan

prorgan@umich.edu

Alex Ruda

Internal Revenue Service

Research, Applied Analytics, and Statistics $77 \mathrm{~K}$ Street NE

Washington, DC 20222

Alexander.C.Ruda@irs.gov

\author{
Joel Slemrod \\ University of Michigan \\ 701 Tappan Street \\ Room R5396 \\ Ann Arbor, MI 48109-1234 \\ and NBER \\ jslemrod@umich.edu \\ Alex Turk \\ Internal Revenue Service \\ 30 East 7th Street \\ Wells Fargo Place \\ St. Paul, MN 55101 \\ Alex.H.Turk@irs.gov
}




\section{Introduction and motivation}

According to the canonical model of Allingham and Sandmo (1972), tax evasion is constrained by the threat of detection and punishment. Traditionally, the punishment for actions deemed to be evasion has been largely financial and, very occasionally, imprisonment. But there is a third tool, known as a collateral sanction. Blank (2013) defines these as measures that are applied in addition to formal tax penalties, rescind government-provided benefits or privileges, and are usually enforced by an agency other than the tax agency. Although empirical analyses of the effectiveness of traditional enforcement policies have recently proliferated, as surveyed in Slemrod (2019), little attention has been paid to the effectiveness of collateral sanctions.

This paper addresses that gap by examining a recent U.S. initiative that can restrict passport access - denying an application or renewal, and even revocation of an existing passport- to taxpayers with substantial tax debt. We estimate the direct and indirect effects on taxpayer behavior of this new authority, including specifically, but not limited to, the effects on payment speed and amount, the likelihood of entering into an installment agreement, and the likelihood of bankruptcy filing. Of the direct effects, we examine the impact of having a passport application denied as well as receiving notification that certification of such an action has been initiated. We take advantage of a randomized controlled trial (RCT) embedded in the certification to identify the latter effect. To study the indirect effects of the program, we analyze trends in taxpayer counts and balances over time, look for bunching under the statutory threshold, and plan to study the total effect of the program by studying how behavior changes over time for cohorts impacted differently by the program.

Understanding both the direct and indirect effects of this program is critical for analyzing the costs and benefits of the program, as well as for optimizing the design of this and other similar programs. It also fleshes out a central component of the Allingham-Sandmo model of tax evasion, the expected penalty for non-compliance, which depends not only on the ability of the tax agency to detect non-compliance but also on its ability to collect any assessed liability.

The collateral sanction we examine - restricting passport access for certain tax debtors - was enacted as part of the Fixing America's Surface Transportation (FAST) Act of 2015, which was 
passed by Congress on December 3 and signed by President Obama a day later. ${ }^{1}$ This Act required the Internal Revenue Service (IRS) to notify the State Department of taxpayers owing a seriously delinquent tax debt (initially $\$ 50,000$ or more, $\$ 54,000$ or more as of 2021 ). The State Department may then deny passport applications or renewals for these taxpayers, and may also revoke existing passports. In February 2018, the IRS began notifying taxpayers of their certification with Notice CP508C and sending certifications of unpaid tax debt to the State Department. TIGTA (2019) discusses some issues with its implementation.

To put into perspective the enforcement potential of the passport sanction program, according to GAO (2011), in fiscal year 2008, of the 16 million passports issued, 224,000 were issued to individuals who owed a total of $\$ 5.8$ billion in unpaid federal taxes. The TIGTA (2019) report provides a snapshot of the passport certification program as of May 17, 2019. By that date, the IRS had certified 388,701 taxpayers as having "seriously delinquent tax debt" under the FAST Act. $^{2}$ A total of $\$ 961$ million in payments had been made to these taxpayer accounts, including $\$ 551$ million in fully paid balances. As a result of these collections efforts, over 40,000 taxpayers had received decertifications for having paid in full or otherwise moving towards being tax compliant. This accounted for $40 \%$ of all decertifications through May 17, 2019, with the remaining $60 \%$ of decertifications resulting from taxpayers falling into one of several categories, the most prevalent being taxpayers living in disaster zones (27\%), whose tax debts have become uncollectible due to statute expiration (12\%), or qualifying for hardship exemptions (9\%).

What these numbers do not reveal is the counterfactual-how much of this debt would have been paid off in the absence of the passport sanctions program - and therefore they do not provide an estimate of the causal impact of the passport revocation program. In this paper we take advantage of micro-level tax administration data and a randomized control trial embedded in the implementation of the program to provide credible causal estimates of its impact.

\footnotetext{
${ }^{1}$ The idea was first introduced in fall 2011 as part of Sen. Barbara Boxer (D-CA)'s bill called MAP-21, a precursor to the FAST Act (Urist (2012)). There is some precedent for restricting access to passports for certain individuals; the Conference Report on the FAST Act notes that under then-present law, the Secretary of State could "refuse to issue or renew a passport if the applicant owes child support in excess of $\$ 2,500$ or owes certain types of Federal debts." (U.S. House (2015)

2 The report notes that this includes some repeat certifications, where a taxpayer was certified, de-certified, and later certified again. In this paper, we focus on first-time certifications.
} 
We find clear evidence that a substantial fraction of those having a passport application denied immediately take action to remove the certification of such an action. There is also compelling evidence that just receiving the certification notification causes a non-trivial, although smaller, fraction of indebted taxpayers to take action leading to decertification. The most common such action is entering into an Installment Agreement, in which the taxpayer commits to paying down their tax debt over time. In contrast to the direct effects, we do not find compelling evidence of an indirect effect by which taxpayers below the certification threshold take actions to ensure that their tax debt does not exceed the eligibility threshold in the future.

The rest of the paper proceeds as follows. Section 2 discusses previous research on the use of collateral sanctions and other tax compliance tools. Section 3 provides institutional details about the passport program, and Section 4 describes the data we use. Section 5 then describes our estimates of the direct effects of the passport program. Section 6 considers the indirect effects of the passport program. Section 7 discusses the policy implications of our results, and Section 8 concludes.

\section{Background and previous literature}

Until the passport provisions of the FAST Act, federal use of collateral sanctions for tax purposes was minimal--failure to pay taxes may result in the loss of ability to apply for FHA mortgages and enter into contracts with the federal government. States have been more active users of collateral sanctions. Some suspend drivers' licenses and vehicle registrations (e.g., California), revoke law and professional licenses (e.g., Minnesota and Wisconsin), or deny hunting and gaming permits (e.g., Louisiana). Criminal convictions result in a wide range of collateral sanctions.

Blank (2013) offers several reasons why a collateral sanction may be more effective than a monetary penalty: it may be more salient: as a denial of an existing service, it may trigger loss aversion; and it may affect one's reputation. Kuchumova (2018) formalizes a rationale for their use: by affecting consumption and providing enforcement targeted to a group, collateral tax sanctions can allow the government to impose punishment correlated with an individuals' earning potential. On the other hand, as Polinsky and Shavell (2000) note, for non-monetary sanctions such as a collateral sanction (or, e.g., imprisonment), the private cost to the sanctioned party is not matched by an equal transfer to the government as it would be for a monetary 
penalty. This drawback of collateral sanctions may be mitigated if the resource cost of administering the public good affected by sanctions is reduced by less demand due to the sanctions (in our case, administering passports may be less costly if demand for passports is reduced by tax debt-related certifications and revocations).

The passport authority is not the only collateral sanction the U.S. government can use to collect tax debt. A "Notice of Federal Tax Lien" (NFTL) can be filed for tax assessments that are not paid. The filing makes the otherwise private debt public information, and helps to establish the government's lien on the taxpayer's assets. This can impact the taxpayer's (individual and business) credit rating and the ability of the taxpayer to sell or refinance assets. Turk et al. (2016) use an event study to examine the impact of NFTL policy changes that were put in place during the great recession. The paper also includes a summary of previous research on the impact of the NFTL the taxpayers. Collins et al. (2018) study the NFTL impact versus direct contact in a randomized control trial. Most of the previous research points to significant effects of NFTL filing policy on debt resolution and (to a lesser degree) indirect effects on payment compliance.

Although as noted above there is some theoretical literature on collateral sanctions, there is relatively little empirical work quantifying the effects of sanctions in practice. Kenchington and White (2021) study Missouri's policy of suspending the professional licenses of those who are noncompliant on their state income taxes, finding that license suspensions are relatively common for lower-income professions. They interpret this as evidence that for some, tax noncompliance is driven by financial constraints rather than unwillingness to pay. Angaretis et al. (2021) study California's "Top 500" tax delinquent publication scheme, which in addition to publicizing the names of the taxpayers with the largest unpaid state tax liabilities also can include suspension of professional, driver's, and other licenses. Comparing the payment trends of published taxpayers with and without licenses, the authors argue that the threat of license suspension appears to induce a positive compliance response. Our paper adds to this growing literature by providing the first evidence of the effect of a large-scale collateral sanction at the Federal level.

Collateral sanctions are just one of a set of tools used by tax agencies to influence tax compliance. For a summary of the broader literature that analyzes the impact of enforcement policies on tax compliance, see Slemrod (2019). 


\section{Passport certification and revocation program}

\subsection{Certification and notification}

The first step in the passport program for substantial tax debtors is a determination of which taxpayers are "certified" to have eligible debt over the threshold. Certification applies to "modules" - basically, a taxpayer-tax year combination. If the sum of tax due and assessed interest and penalties on all eligible modules exceeds the threshold, all of the eligible modules are certified. For a module to become eligible, it must constitute "seriously delinquent tax debt" by meeting at least one of two inclusion requirements, and not meet any of a number of exclusion requirements. The two inclusion requirements require that the module either has had a Notice of Federal Tax Lien filed and the associated Collection Due Process (CDP) hearing rights have expired, or a Notice of Levy has been issued. The exclusion requirements exempt modules that meet any of a set of detailed criteria, the most common of which are being part of an approved or pending Installment Agreement or Offer-in-Compromise, about which we have more to say below. For more details on specific eligibility and ineligibility criteria, and the treatment of certain special cases, see the Appendix.

The threshold was set at $\$ 50,000$ initially and is indexed for inflation, rising to $\$ 51,000$ in 2018 , $\$ 52,000$ in $2019, \$ 53,000$ in 2020 , and $\$ 54,000$ in 2021 . The relevant balance for this threshold is assessed balance due, interest, and penalties. Interest and penalties that accrue over the time after assessment is made do not influence whether a taxpayer is eligible for certification or not. Once modules have been certified, a taxpayer must pay off or otherwise deal with all of the certified module debt in order to be decertified. For example, suppose a taxpayer has eligible modules from three tax years with assessed amounts of $\$ 25,000, \$ 20,000$ and $\$ 10,000$, for a total of $\$ 55,000$. This breaches the threshold and each of these three modules is certified. The taxpayer must then resolve each of these three to become decertified; for example, only resolving the $\$ 10,000$ module (resulting in $\$ 45,000$ of remaining eligible balance, below the threshold) will not suffice.

About two weeks after certification, both the IRS and the State Department send letters to the taxpayer notifying them of their certification. ${ }^{3}$ The IRS letter is called a 508C Notice; it indicates

\footnotetext{
${ }^{3}$ The delay between certification and notification by the IRS allows the IRS and State Department to send their letters at roughly the same time.
} 
the total balance identified as seriously delinquent, broken down into tax debt, penalties, and interest, and subsequently broken down by tax period. The letter informs the taxpayer that as a result of certification: ${ }^{4}$

\begin{abstract}
If you apply for a passport or passport renewal, the State Department will deny your application and will not issue a passport to you or renew your current passport. If you currently have a valid passport, the State Department may revoke your passport or limit your ability to travel outside the United States.
\end{abstract}

Figure 1 shows the monthly count of certifications, separately counting first-time certifications (in gray) and subsequent certifications for the same taxpayer (in orange). ${ }^{5}$ When the program began there were about 200,000 taxpayers who were eligible for certification, and most of these taxpayers were certified in waves over the months of March-July, 2018. After this initial rollout, the program has maintained a regular weekly certification of several thousand newly eligible taxpayers each month. Some cases involving "complex debt"- those with aggregate debt from multiple filing statuses - were not included in the initial rollout of the program due to the more complicated programming needed to ensure accurate certification. In early 2020 , these complex debt cases were added to the program. Passport certification was paused in April 2020 due to COVID-19.

\footnotetext{
${ }^{4}$ Beginning in 2016, similar language informing taxpayers about the passport program began to be included on other IRS notices sent to taxpayers as part of the normal collections process. Although this information was not the focus of those notices, its inclusion may have alerted some taxpayers about the potential for their future certification. To the extent this happened, our analysis of the effect of the passport program may represent a lower bound, as those individuals most responsive to the program may have seen references to it in earlier notices and responded preemptively.

${ }^{5}$ Subsequent certifications can happen for a number of reasons. For example, a taxpayer with existing modules that are certified may accrue new tax debt, which is subsequently certified. Or, a taxpayer may take action to become decertified on previously certified debt, and then because of later actions become eligible again for certification.
} 
Figure 1: Monthly count of certifications (first-time and subsequent instances)

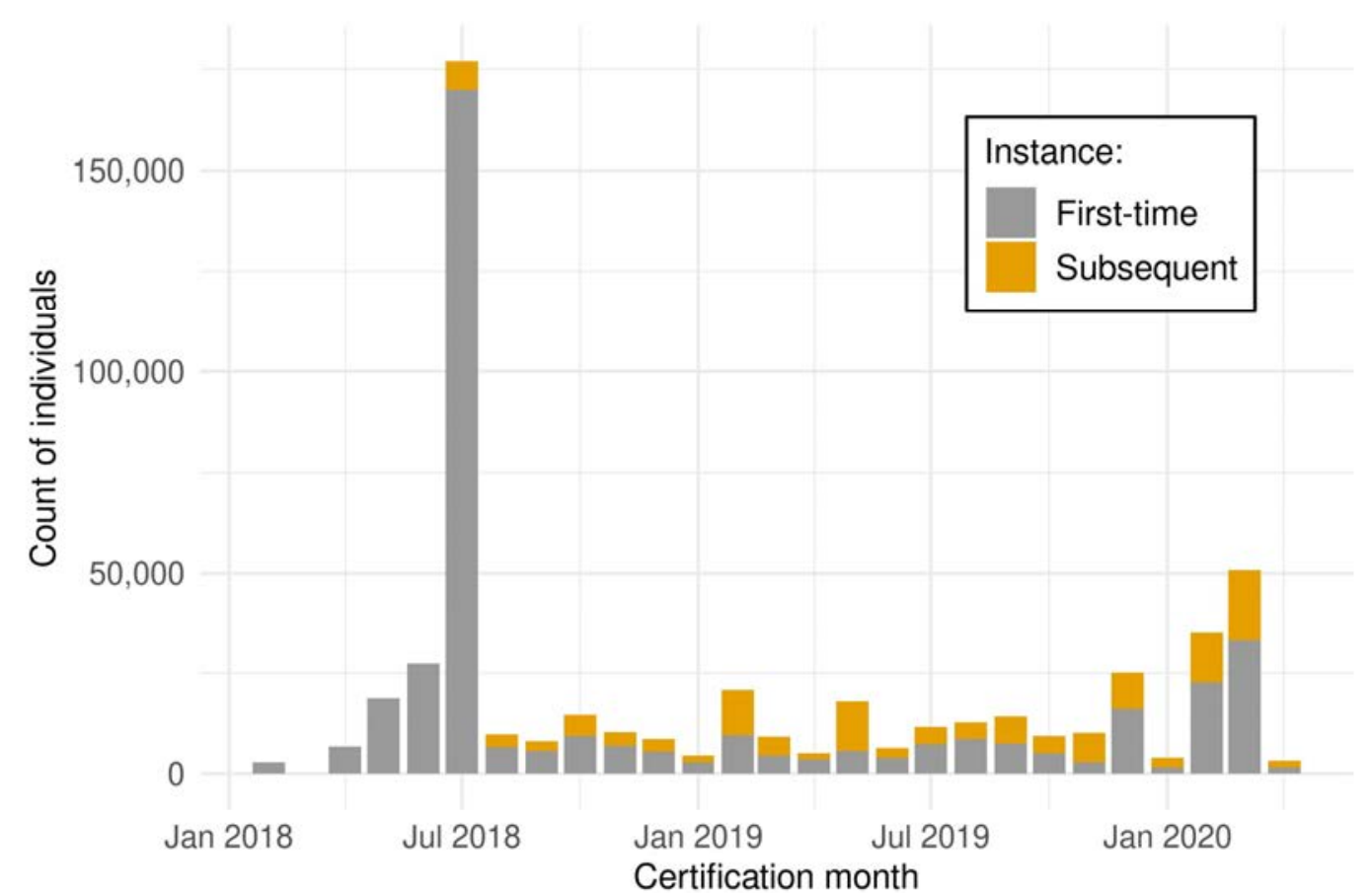

Notes: This figure plots the monthly count of individuals having tax debt newly certified under the passport program. In gray are individuals with tax debt certified for the first time; in orange are individuals with tax debt certified for a second or subsequent time.

\subsection{Decertification}

A certified taxpayer can get decertified by completely satisfying all of their certified tax debt, either by paying in full, by initiating an Installment Agreement (IA), or by successfully making an Offer in Compromise (OIC). ${ }^{6}$ Previously certified taxpayers can also subsequently become ineligible for inclusion in the program by newly meeting a statutory exclusion criterion, such as by being designated as Currently Not Collectible (CNC)-Hardship, or by filing for bankruptcy. Figure 2 shows the monthly count of decertifications, separately counting first-time decertifications (in gray) and subsequent decertifications for the same taxpayer (in orange).

\footnotetext{
${ }^{6}$ Installment Agreements are plans to pay off a tax bill over an extended period; they must be approved by the IRS. Offers in Compromise allow a taxpayer to settle her tax debt for less than the full amount; they must also be approved by the IRS.
} 
Figure 2: Monthly count of decertifications (first-time and subsequent instances)

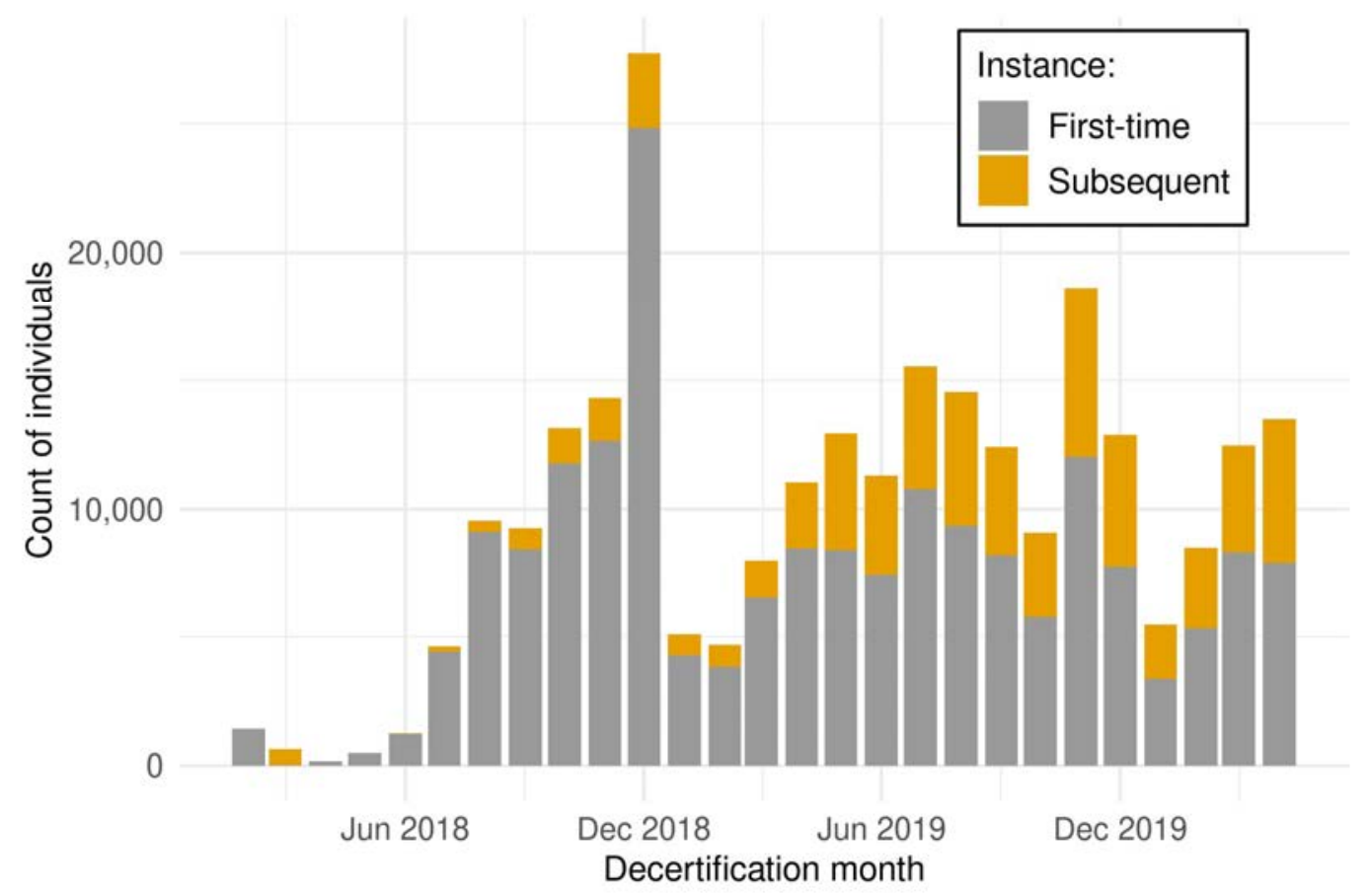

Notes: This figure plots the monthly count of individuals having their tax debt certification under the passport program reversed. In gray are individuals with tax debt decertified for the first time; in orange are individuals with tax debt decertified for a second- or subsequent time.

How to get decertified is a question that many certified taxpayers themselves may have asked. As Figure 3 shows, strong patterns are visible in traffic to the IRS webpage describing the passport program. ${ }^{7}$ The webpage was first published in January 2017, and several news articles linked to it on February 3, 2017, resulting in the largest single day of page visits. Visits also increased significantly in June and July 2018, when the largest number of certifications and notifications occurred.

\footnotetext{
${ }^{7}$ https://www.irs.gov/businesses/small-businesses-self-employed/revocation-or-denial-of-passport-in-case-ofcertain-unpaid-taxes
} 
Figure 3: Daily page views for IRS passport program webpage

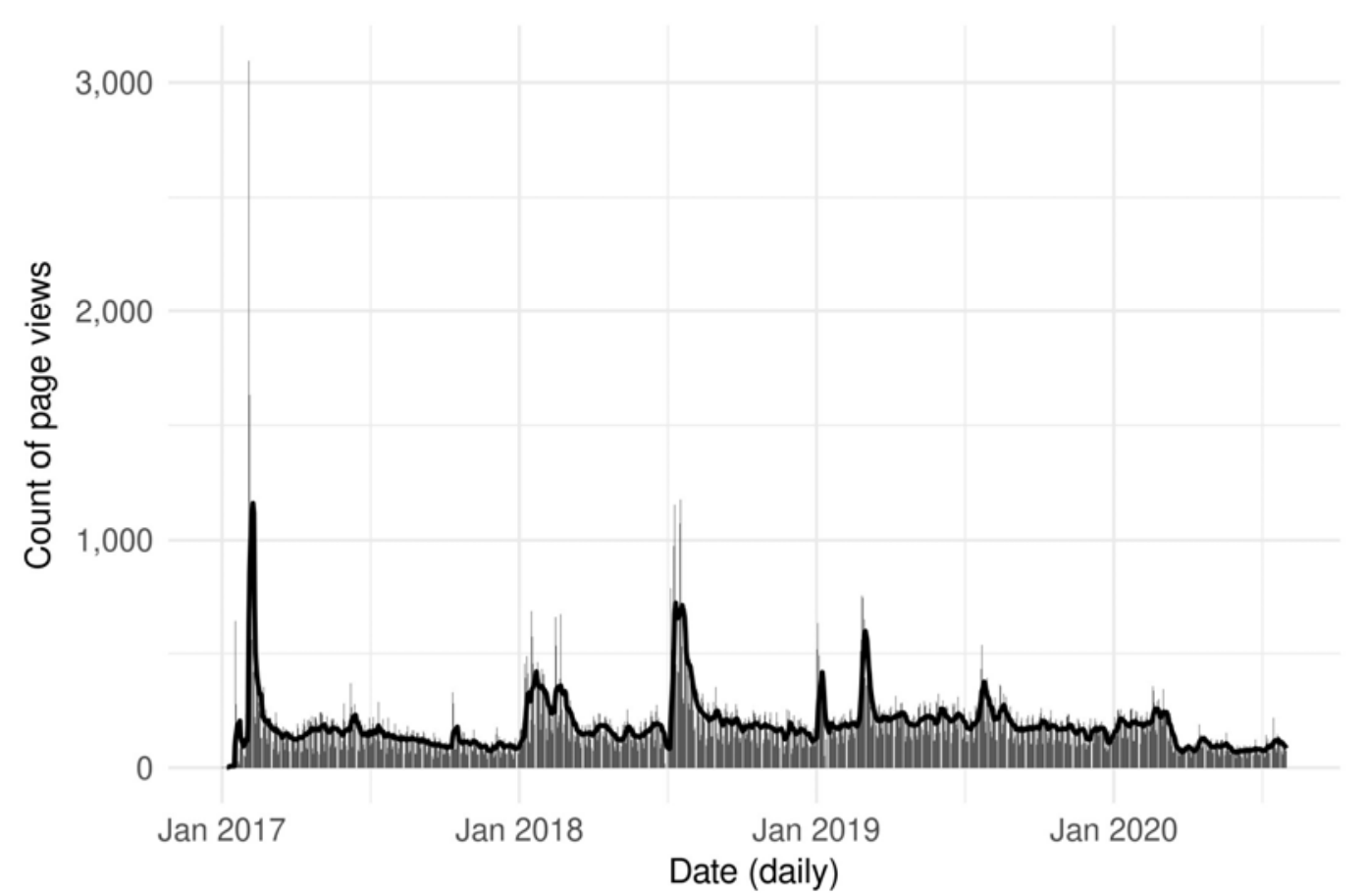

Notes: This figure plots the daily page visits to the IRS webpage describing the passport certification and revocation program. The gray bars present the daily visits; the black line presents the priorseven-day rolling average.

\subsection{Passport-related consequences of certification}

For most certified taxpayers, the consequence of certification would be the denial of their application for a new passport or for renewal of a passport. In certain cases, the IRS may recommend that the State Department revoke an existing passport; the State Department makes the final decision. As of January 2020, about 10,000 certified taxpayers had tried to do something passport-related and have been denied (new application, renewal, modification). We study these taxpayers' subsequent behavior below.

\section{Data}

The main source of data for this study is a set of IRS databases tracking unpaid tax assessments, taxpayer activity, and IRS notice issuances. For each module (a taxpayer-tax period combination), we observe monthly the balance due, including separately both assessed and accrued balances, penalties, and interest. We also observe, monthly or weekly, taxpayer activity concerning a number of outcomes of interest, including payments, entering into new Installment 
Agreements, proposing and having accepted Offers-in-Compromise, and designation as CNC due to hardship or having filed for bankruptcy. Finally, we observe records indicating which modules are certified and decertified, and when.

We do not know which taxpayers have passports, which of those are soon to expire, and which taxpayers don't have passports but plan to get them in the future. The State Department provides data on passport issuance by state, and from that data one can infer some patterns in the demographics of passport holders. We are able to match taxpayers to their tax filings, and use that matched information to proxy for passport ownership (for example, by noting that those with higher income are more likely to have or want passports).

Because not all taxpayers have passports, and among those who do only some will require changes or renewal within a few years, we do not expect the passport program to change the behavior of every certified taxpayer. Table 1 provides some context for the number of tax debtors and amount of tax debt that could be expected to be materially affected by the program, as of May 2018. If we assume that the fraction of individuals with passports in the country as a whole, $42 \%$, applies to eligible debtors, and that about $20 \%$ of passport-holders seek renewal in a twoyear period, then about 30,000 certified taxpayers would face a refused renewal application within that time period. Making the same assumptions about the dollar value of debt implies that about $\$ 6$ billion of tax debt would be immediately impacted, or less than $3 \%$ of the total outstanding debt. Although these are of course just approximations, they highlight that the passport program might not have immediately impacted all of the total tax debt in a substantial way. One caveat to this argument is that it assumes taxpayers understand that certification will likely only affect them if and when they apply for passport renewal; if instead, taxpayers perceive certification to mean that their active passports will be revoked, then one might expect a stronger or quicker response. ${ }^{8}$

\footnotetext{
${ }^{8}$ Some news articles about the passport program may have led taxpayers to think that revocation was likely. See, for example, Gonçalves (2018), "IRS to revoke 260,000 American passports" or Phillips Erb (2017), "If You Owe Taxes to IRS, You Could Lose Your Passport and Your Ability to Fly."
} 
Table 1: Estimate of potentially treated population size

\begin{tabular}{lrr}
\hline \hline & Taxpayers (\#) & Debt (\$B) \\
\hline Individual income tax filings for 2017 & $150,690,787$ & \\
Individuals with outstanding tax debt in May 2018 & $16,811,000$ & 252.28 \\
Assessed debt > \$50 thousand & 768,000 & 157.92 \\
Eligible for certification & 348,000 & 68.32 \\
Having a passport & 146,160 & 28.69 \\
Passport needing renewal in next two years & 29,232 & 5.74 \\
\hline \hline
\end{tabular}

Notes: This exercise assumes that $42 \%$ of individuals have passports (based on the State Department's count of valid U.S. passports in circulation relative to the U.S. population in 2018), that $20 \%$ of passports require renewal in the next two years (most passports are valid for 10 years), and that passport holding and renewal are uniformly distributed. Debt includes assessed balance due, penalties, and interest, but excludes accrued interest and penalties.

\section{Direct effects of the passport program}

The passport program could affect debt and debt repayment in two ways. First, it could induce taxpayers with eligible debt above the threshold to take action that would lead to decertification, which can occur either by resolving their debt (paying in full, entering into an Installment Agreement, or making an Offer-in-Compromise) or by taking another action such as filing for bankruptcy, obtaining a CNC-Hardship designation, and/or providing documentation resulting in some or all of the balance being abated (e.g. providing an original return in response to a "Substitute for Return" tax assessment). We refer to these actions as the direct effect of certification.

The passport program could also affect debt and debt repayment by inducing taxpayers with tax debt below the eligible threshold to take actions so that they do not become eligible and thereby leave themselves open to passport certification; it could also affect the efficacy of other enforcement tools, like liens and levies, that are prerequisites for passport certification. We call these the indirect effects of the program.

In this section we focus on the direct effects of the passport program, and consider the indirect effects in the following section. There are two key aspects of the program that allow us to credibly estimate its causal impact: the denial of passport-related requests for a non-trivial 
number of certified taxpayers and the presence of a randomly chosen holdout group during the program rollout. ${ }^{9}$ In what follows we pursue in turn what each of these design features can tell us about the impact of the passport certification and revocation program.

\subsection{Effect of denied passport-related actions}

As of January 2020, about 10,000 certified taxpayers had tried to do something passport-related and been denied (new applications, renewals, modifications). ${ }^{10}$ This population offers the clearest opportunity to study a direct effect of certification, as these are taxpayers who are certainly treated by the program (in contrast to certifications more generally, where taxpayers are only effectively treated when certified if they anticipate wanting to make passport-related requests in the near future). We refer to this set of taxpayers as the "State Denied" group.

To shed light on this, we next show the share of these taxpayers taking various actions in the months before and after their passport-related requests were denied by the State Department due to their certified status. One potential concern is that any graph of the share taking action, conditional on being certified in the prior month, may show some increase in such activity simply because, in order to be certified, one must not have taken any actions leading to decertification, and thus the probability of taking these actions in the following month must increase, or at least stay the same; we call this the mechanical effect. To address this concern, we compare the behavior of the State Denied taxpayers to a control group. We take a random sample of taxpayer-month observations among currently certified taxpayers, and call the sampled month $\mathrm{t}=0$ for each of these taxpayers. We then observe their behavior in the months before and after, and similarly calculate the share of this control group taking actions in each relative month. This group can still exhibit the mechanical effect (action in month $\mathrm{t}=1$ may jump up simply because we condition on being certified in month $\mathrm{t}=0$ ). Thus, comparing the behavior between the State Denied group (showing treatment + mechanical effect) and the control group (showing only the

\footnotetext{
${ }^{9}$ Another feature of the program that may be useful for estimating its causal impact is the statutory threshold for eligibility, which began at $\$ 50,000$ and has risen $\$ 1,000$ each year since 2018 . Ideally one could compare taxpayers above and below the threshold to learn about the causal impact of certification. The potential of this analysis is undermined by the fact that other IRS policies (e.g., streamlined Installment Agreements) feature cutoffs at $\$ 50,000$ of debt, which make it less likely that taxpayers just above and below the cutoff are appropriately comparable and any differences between these two groups are attributable to the passport program.

${ }^{10}$ The total number of certified taxpayers with a request denied by the State Department as of January 2020 was about 12,000, of which about 2,000 appear as secondary taxpayers with joint tax liabilities (spouses on joint tax returns). To avoid double counting, we exclude denials related to secondary taxpayers, and analyze only denials related to the taxpayer listed as the primary taxpayer.
} 
mechanical effect) allows us to see the effect of the denial of a passport-related request as the difference between the two groups.

Figure 4 compares the share of the State Denied group and the control group that were newly decertified in each month. We show six months before and twelve months after $t=0$ (the month in which a passport request was denied for the State Denied group, in orange, or the randomly selected month for the control group, in gray). ${ }^{11}$ The graph shows clearly that the denial of a passport-related request leads to an immediate jump in new decertifications for the State Denied group, above and beyond the mechanical effect that can be seen in the smaller jump for the control group. Between month $\mathrm{t}=0$ and month $\mathrm{t}=6$, the cumulative difference in new decertifications is about 20 percentage points (50\% for the State Denied group vs. $30 \%$ for the control group).

Figure 4: Share getting newly decertified, State Denied vs. control group

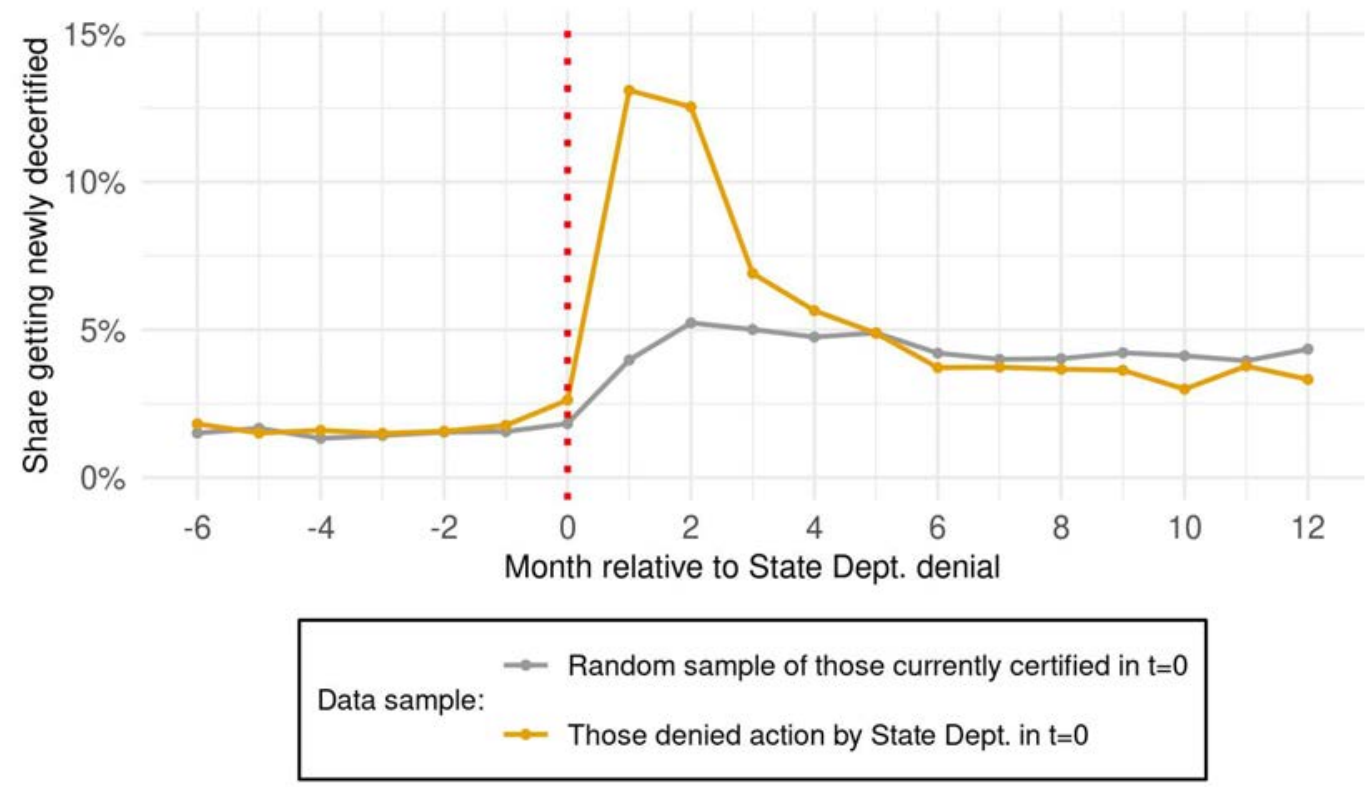

Notes: This figure plots the share of each of two groups newly getting decertified in each month. In orange is the State Denied group, whose passport-related requests were denied in month $t=0$. In gray is the control group, a random sample of taxpayers who were certified as of month $\mathrm{t}=0$.

\footnotetext{
${ }^{11}$ We stop our outcome observations for this analysis in February 2020, to avoid any change in behavior due to COVID-19, which among other things undoubtedly reduced the immediate value of holding a passport due to travel restrictions. This means that not all taxpayers have twelve months of post- $\mathrm{t}=0$ data. The count of taxpayers with available data, and thus who are included in the monthly share calculations, are shown in the Appendix, Figure 15.
} 
We next consider separately the primary actions a taxpayer can take to get decertified. We first look to see whether taxpayers fully resolve their balance, which we identify by observing their assessed balance, penalties, and interest going to zero. This can happen because a taxpayer makes payment in the full amount; it can also happen because the taxpayer provides additional information or filings leading to the amounts being abated. We classify instances in which balances going to zero into these two groups (payment and abatement) and a third group including those going to zero without payments or abatements. ${ }^{12}$ Figure 5 below compares the share of taxpayers in the State Denied and control groups taking each action (full resolution by each of three means), in the months relative to State Department denial. The State Denied group is more likely to fully resolve both by payment and by abatement, with payment about five times as common as abatement. The two groups are roughly equally likely to fully resolve by other means.

\footnotetext{
${ }^{12}$ Specifically, if a taxpayer's balance goes to zero and their payments total at least $90 \%$ of the starting balance, we classify this as a full resolution by payment. If abatements total at least $90 \%$ of the starting balance, we classify this as a full resolution by abatement. Taxpayers with balance going to zero that do not have large payments or abatements are classified as full resolution by other means.
} 
Figure 5: Share fully resolving balances, State Denied vs. control group

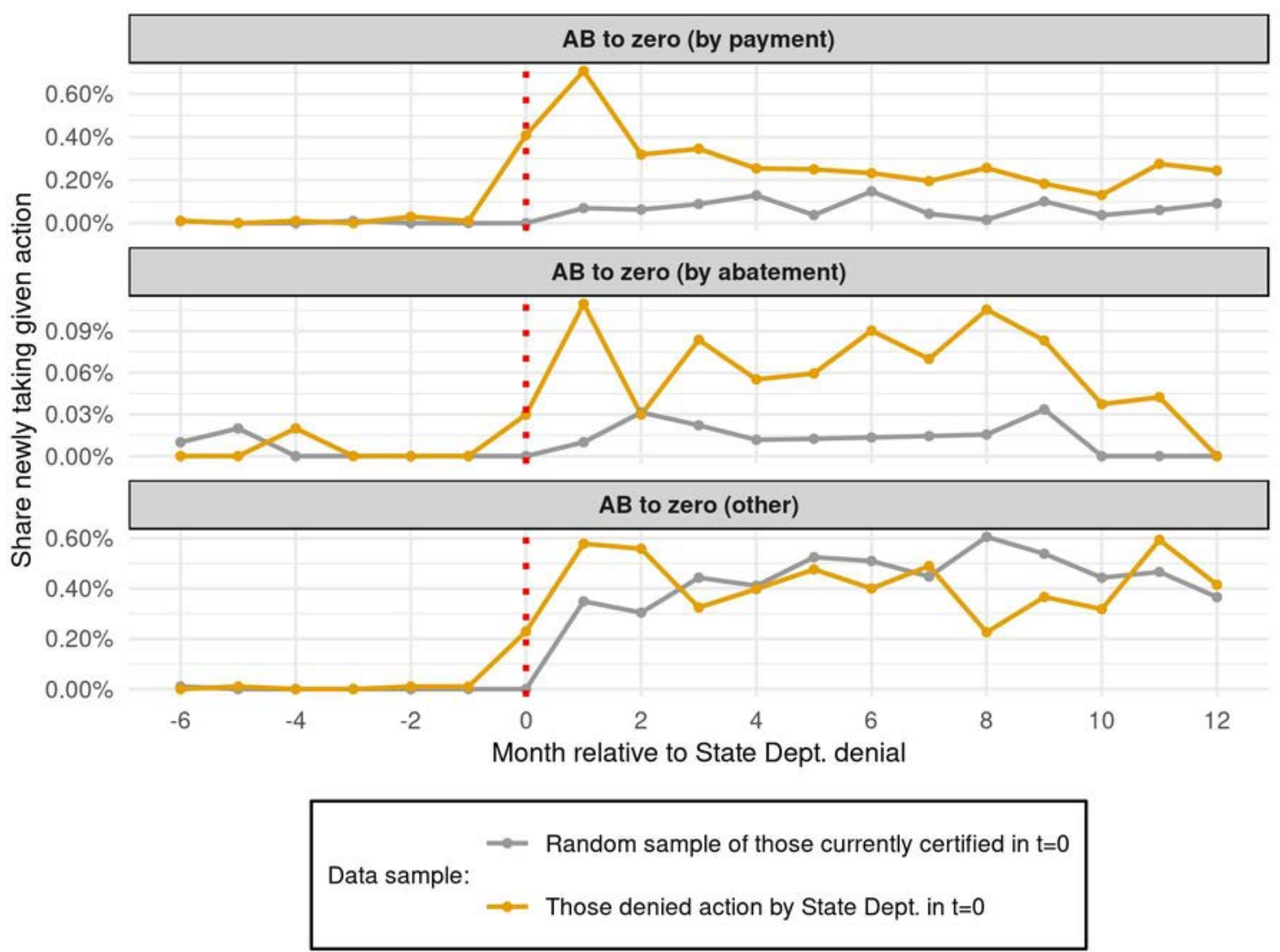

Notes: This figure plots the share of each of two groups newly resolving their balance in full, either by payment, abatement, or other means. In orange is the State Denied group, whose passport-related requests were denied in month $\mathrm{t}=0$. In gray is the control group, a random sample of taxpayers who were certified as of month $\mathrm{t}=0$.

In addition to resolving the balance in full, a taxpayer can come into compliance and get decertified by starting an Installment Agreement (IA) or making a successful Offer-inCompromise (OIC). Taxpayers can also get decertified by filing for bankruptcy or being designated as Currently Not Collectible due to hardship. All of these actions are typically precipitated by a response from the taxpayer regarding their unpaid liabilities. Figure 6 below compares the share newly taking each such action between the State Denied and control groups. The State Denied group is more likely to enter into new IAs, OICs, and CNC designations, with IAs about 10 times as likely as OICs, and twice as likely as CNCs. ${ }^{13}$

\footnotetext{
${ }^{13} \mathrm{We}$ can also split these samples further based on their recent income tax filings to understand more about the types of taxpayers taking each action. We find that those with above-median income are more likely to respond by
} 
Figure 6: Share taking new actions leading to decertification, State Denied vs. control group

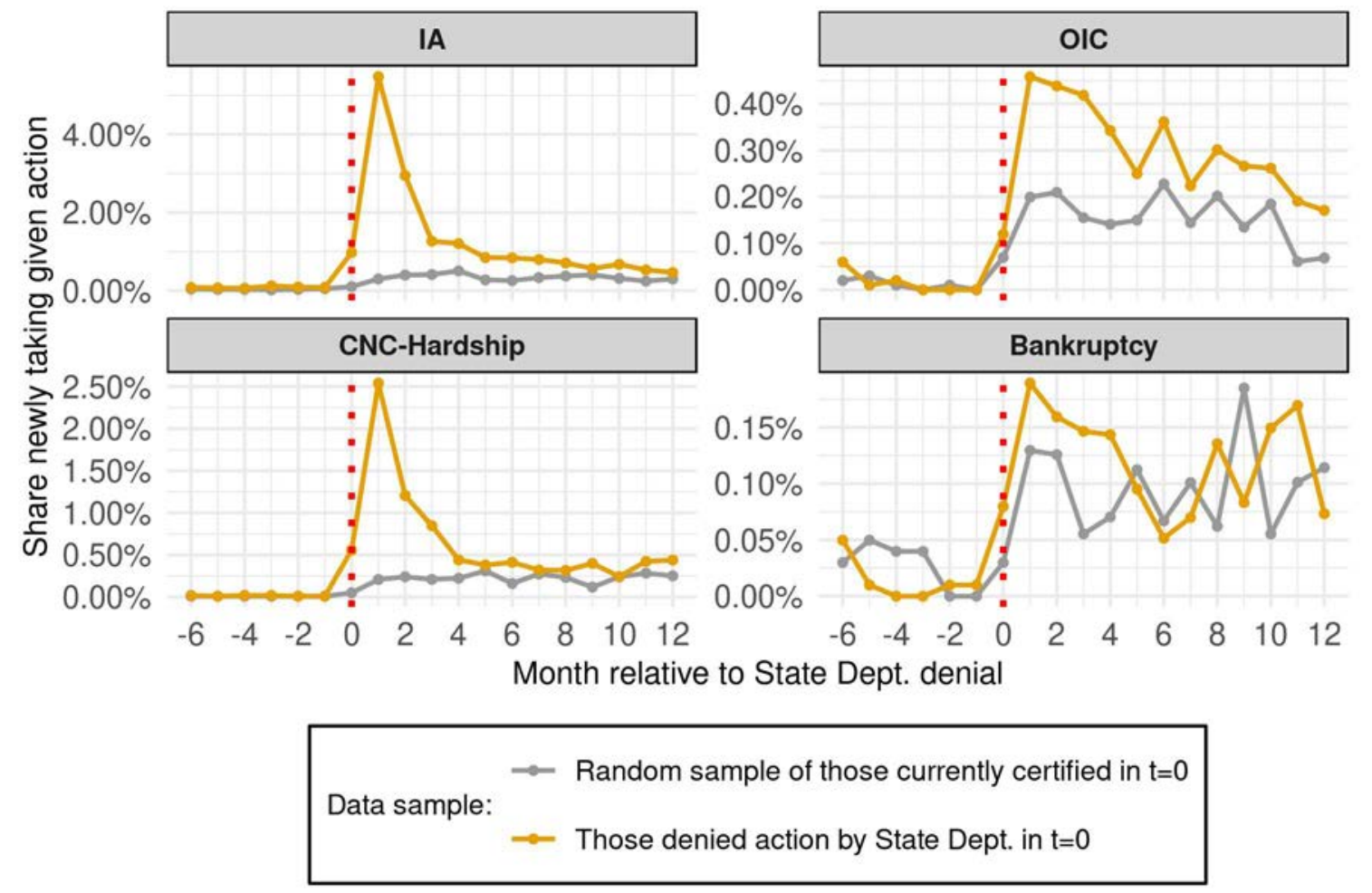

Notes: This figure plots the share of each of two groups newly entering into each status in each month, for the main actions that lead to decertification. In orange is the State Denied group, whose passport-related requests were denied in month $\mathrm{t}=0$. In gray is the control group, a random sample of taxpayers who were certified as of month $\mathrm{t}=0$. These actions are not necessarily mutually exclusive, nor exhaustive of all actions that can lead to decertification.

The figures above show the month-by-month differences in the share of each group taking action. They show an initial large spike in activity by the State Denied group immediately following denial; this is followed by several months in which the State Denied group remains more active than the control group, generally tapering out over time. To estimate the cumulative effect of State Department denial, we can thus aggregate the difference in activity over the months after State Department denial. Table 2 compares the cumulative share of those newly taking each action over the months $\mathrm{t}=0$ to $\mathrm{t}=6$, demonstrating that State Department denial leads to significant increases in compliance behavior over the six months following denial.

starting a new IA, while those with below-median income are more likely to newly make OICs or enter CNCHardship status. See Figure 16 in the Appendix. 
Table 2: Cumulative share comparison, State Denied vs. control group

\begin{tabular}{lc|ccc|cccc}
\hline \hline & \multicolumn{7}{c}{ Sum of share newly taking each action over months t=0 to $\mathrm{t}=6$} \\
\cline { 2 - 9 } & Decertification & WTZ (Pay) & WTZ (Abate) & WTZ (Other) & IA & OIC & CNC-Hardship & Bankruptcy \\
\hline State Denied group & $49.4 \%$ & $2.5 \%$ & $0.5 \%$ & $3.0 \%$ & $13.6 \%$ & $2.4 \%$ & $6.4 \%$ & $0.9 \%$ \\
Random sample & $29.9 \%$ & $0.5 \%$ & $0.1 \%$ & $2.5 \%$ & $2.2 \%$ & $1.2 \%$ & $1.4 \%$ & $0.6 \%$ \\
Difference & $19.5 \%$ & $2.0 \%$ & $0.4 \%$ & $0.4 \%$ & $11.3 \%$ & $1.2 \%$ & $5.0 \%$ & $0.3 \%$ \\
\hline \hline
\end{tabular}

Notes: This table presents the cumulative share of taxpayers in each group taking each action over months $\mathrm{t}=0$ to $\mathrm{t}=6$. The selected actions leading to decertification are not necessarily mutually exclusive, nor exhaustive of all actions that can lead to decertification. WTZ=Went To Zero balance.

These actions translate into more payments, as well. Figure 7 shows the share of each group making positive net payments in each month, with the State Denied group only slightly above the control group in the pre-period, at around $15 \%$, then increasing by about five percentage points after the denial of their passport requests. In terms of overall assessed balances, however, the effect of new payments (which when applied to balance due would lower the remaining assessed balance) is somewhat offset by the fact that some of the State Denied taxpayers add balance due modules after their denials, increasing their assessed balance. This effect is likely driven by the requirement that taxpayers be current on all tax filings before administrative resolutions such as IAs, OICs or CNCs are granted; taxpayers with unfiled returns for prior tax years must file those returns, which often result in new balance due modules. Although this results in a higher assessed balance, it is a positive compliance outcome; becoming current on filing obligations is an important step towards becoming fully compliant in terms of their remittance obligations. 
Figure 7: Share making payments and adding new modules, State Denied vs. control group

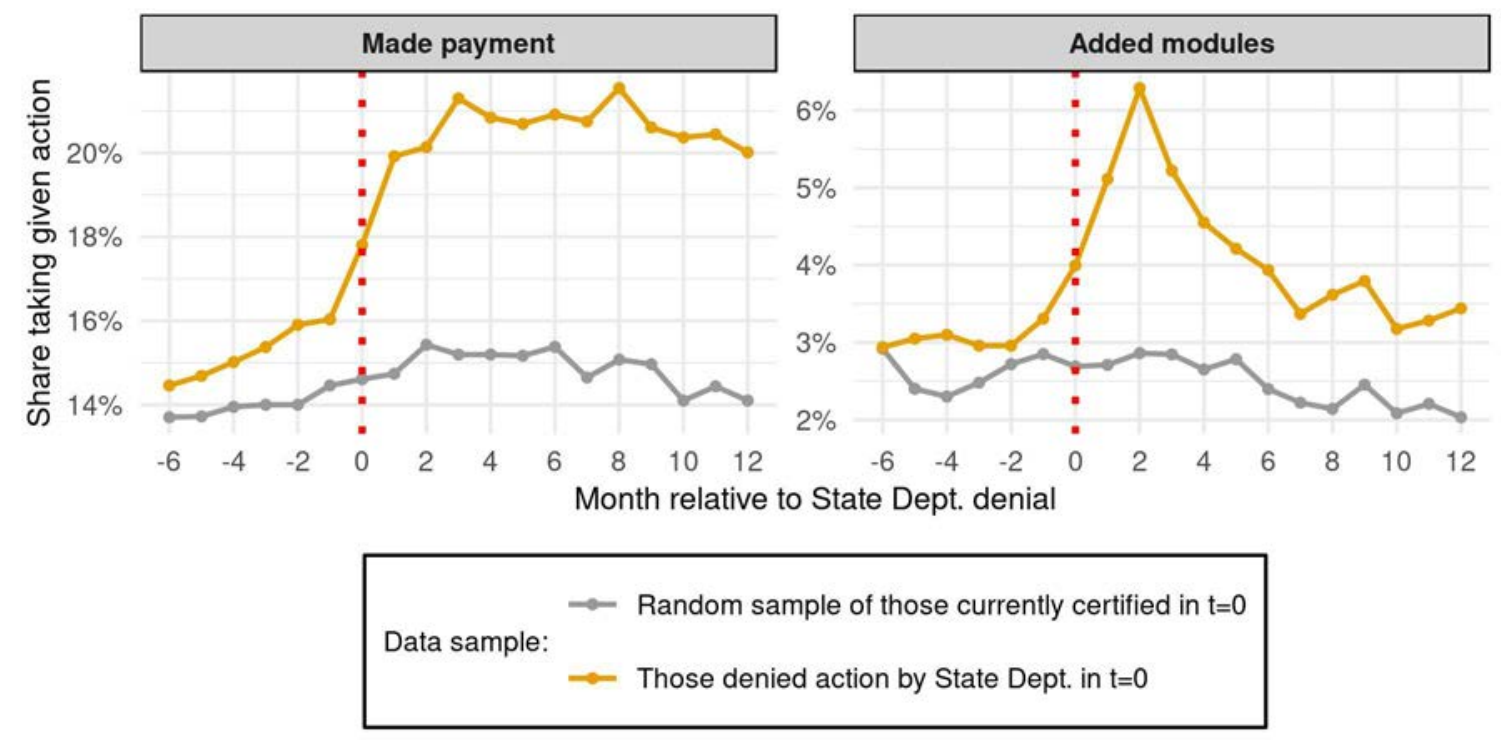

Notes: This figure presents the share of taxpayers in each group that make a payment each month.

The high base share of payments each month is likely due to levies and other automatic payments.

Comparing the balances and payments of the two groups, taxpayers in the State Denied and control groups have similar average assessed balances as of month $t=-1$ of about $\$ 200,000$. Over the six months to $t=6$, the State Denied group experiences a slightly smaller fall in assessed balance compared to the control group, on average. However, as noted above, one effect of denial was to induce some State Denied taxpayers to file previously unfiled returns, resulting in new balance due modules. When restricting to just taxpayers without additional modules, the State Denied group shows a slightly larger fall in assessed balance than the random control group. In both the full sample and the subset of those without new modules, the State Denied group shows larger average payments, and larger average abatements. Taking the difference in cumulative payments between the State Denied group and the control group shows additional payments, on average, over the six months post-denial of $\$ 6,000$, and over the 12 months postdenial of $\$ 9,000 .{ }^{14}$

\footnotetext{
${ }^{14}$ As above for the binary actions, we find a larger payment effect for those with above-median income: over the six-months post-denial the difference in cumulative payments for above-median income taxpayers is $\$ 7,800 \mathrm{vs}$. $\$ 1,500$ for below-median income taxpayers.
} 
Table 3: Balance and cumulative payment comparison, State Denied vs. control group

\begin{tabular}{|c|c|c|c|c|}
\hline & \multicolumn{2}{|c|}{ Among all with end-month data } & \multicolumn{2}{|c|}{ Subset to those not adding new modules } \\
\hline & State Denied & Random sample & State Denied & Random sample \\
\hline \multicolumn{5}{|l|}{ Panel A: 6-month cumulative outcomes } \\
\hline Average assessed balance in $t=-1(\$ K)$ & $\$ 195$ & $\$ 206$ & $\$ 196$ & $\$ 208$ \\
\hline Average assessed balance in $t=6(\$ K)$ & $\$ 187$ & $\$ 194$ & $\$ 178$ & $\$ 190$ \\
\hline$\%$ fall in total assessed balance & $4.3 \%$ & $6.0 \%$ & $9.2 \%$ & $8.5 \%$ \\
\hline Average net payment from $t=0$ to $t=6(\$ K)$ & $\$ 10$ & $\$ 4$ & $\$ 11$ & $\$ 4$ \\
\hline Average abatement from $t=0$ to $t=6(\$ K)$ & $\$ 6$ & $\$ 2$ & $\$ 6$ & $\$ 2$ \\
\hline \multicolumn{5}{|l|}{ Panel B: 12-month cumulative outcomes } \\
\hline Average assessed balance in $t=-1(\$ K)$ & $\$ 201$ & $\$ 190$ & $\$ 201$ & $\$ 186$ \\
\hline Average assessed balance in $t=12(\$ K)$ & $\$ 186$ & $\$ 171$ & $\$ 170$ & $\$ 158$ \\
\hline$\%$ fall in total assessed balance & $7.3 \%$ & $9.7 \%$ & $15.2 \%$ & $15.1 \%$ \\
\hline Average net payment from $t=0$ to $t=12(\$ K)$ & $\$ 15$ & $\$ 6$ & $\$ 17$ & $\$ 6$ \\
\hline Average abatement from $\mathrm{t}=0$ to $\mathrm{t}=12(\$ \mathrm{~K})$ & $\$ 9$ & $\$ 4$ & $\$ 9$ & $\$ 4$ \\
\hline
\end{tabular}

Notes: This table presents average values for taxpayers in the State Denied and control group taxpayers with data available in month $\mathrm{t}=6$ (Panel A) or $\mathrm{t}=12$ (Panel B), to ensure a direct comparison of changes in balance and payments. The left two columns include all such taxpayers; the right two columns restrict the comparison to only those without additional modules, to address the fact that some State Denied taxpayers were induced to add modules in order to take other compliance actions.

We interpret these results as clear evidence that the threat, indeed the reality, of a passport denial or revocation induces positive compliance behavior for a non-trivial fraction of debtors. Two aspects should be noted. First, while about half of the State Denied group took an action to remove the passport restriction during the six months following the denied request, the other half did not take any such action. This suggests that the value of having a passport or renewed passport was worth less to the latter half than the most attractive avenue to decertification. Second, and related, all of these taxpayers were informed this could happen, and they applied for a passport or passport renewal anyway. This suggests they may not be entirely representative of the average taxpayer or tax debtor.

\subsection{Effect of certification using holdout/control groups}


The preceding analysis reveals that having a passport application denied gets the attention and prompts action of a non-trivial fraction of tax debtors. Next, we step back and examine the impact of the certification notification letters, which by the end of 2019 had informed more than 300,000 debtors - or 30 times the number of those with denied applications - that, unless they took action, they would be denied a new or renewed passport.

Identifying the impact of the initial rollout of the certification notification is facilitated by the fact that it was implemented with an embedded RCT. During the first year of the passport program, Social Security numbers (SSNs) were used to randomize whether a certificationeligible taxpayer would actually be certified or not; $5 \%$ of the sample of taxpayers with eligible debt were "held out" from the certification process during the time period studied. The behavior of the holdout group compared to those taxpayers "treated" with a certification notification can provide evidence of the causal impact of certification, as the two groups are on average identical in all characteristics and thus would have on average behaved identically in the absence of the program.

One complication to this strategy arises, however. Due to certain actions or changes in their account characteristics, some of the control-group taxpayers subsequently identified as being eligible for recertification (even though they were in the control group) and on these subsequent occasions were certified. In the terms of Angrist (2005), the RCT implemented here is subject to "treatment migration," wherein some taxpayers in the control group obtain the treatment (certification). We discuss below how we address this issue.

We begin by presenting visual evidence of the effect of certification. Figure 8 shows the difference in certification rates over time between the treatment group (who were eligible for certification and by SSN were intended to be certified) and the control group (who were eligible for certification and by SSN were intended to be held out and have their certification delayed). $100 \%$ of the treatment group had been certified by March 2019, while about $20 \%$ of the control group had been certified by that time, thus leaving about $80 \%$ of the control group who had not "migrated." 
Figure 8: RCT analysis, comparison only by SSN groups, certification

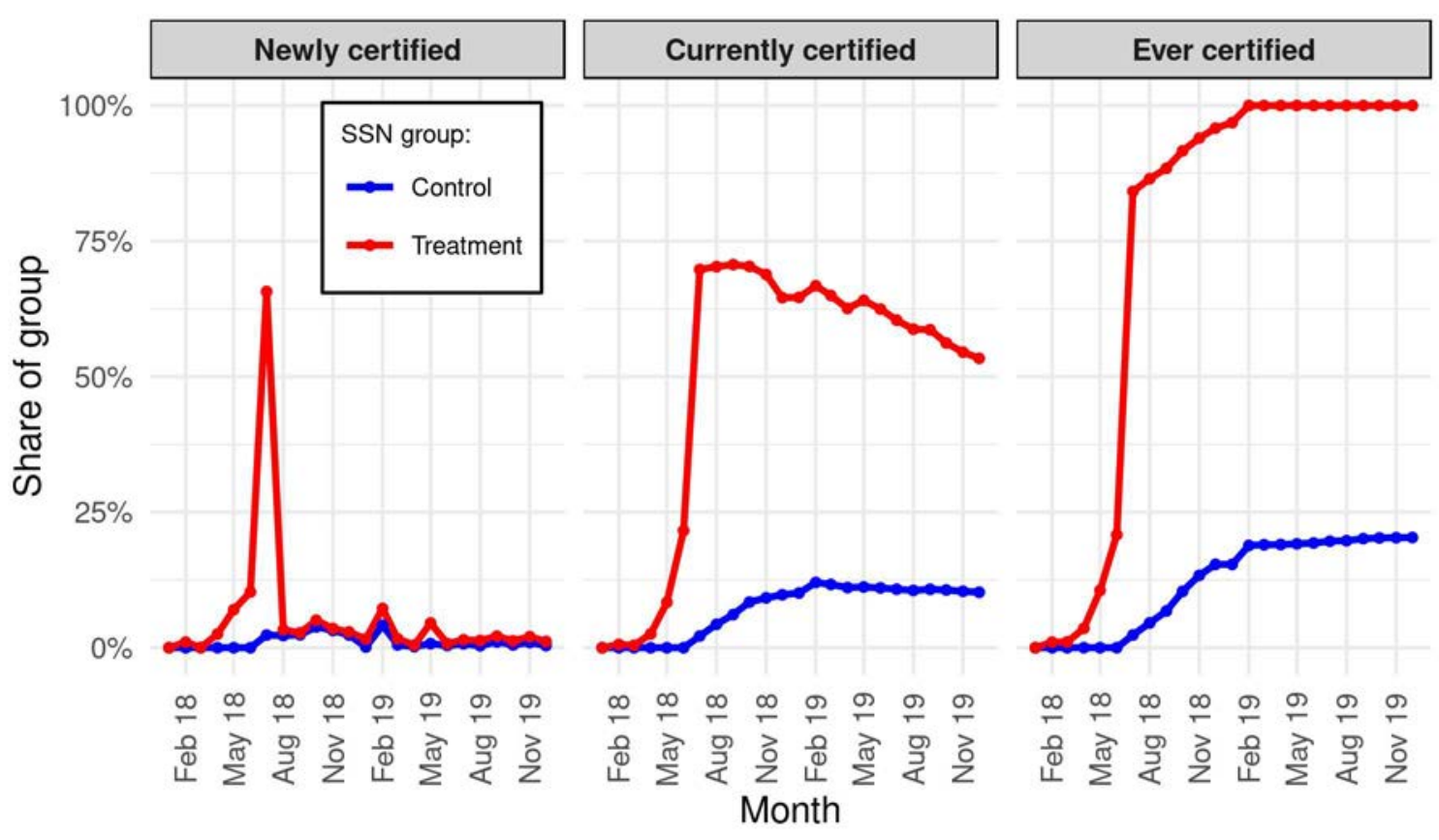

Notes: This figure compares taxpayers who by SSN were assigned to the treatment or control group during the rollout of the passport program. A wrinkle in the program implementation led roughly $20 \%$ of control group taxpayer to migrate into treatment (certification) over time.

Consistent with the patterns seen above for the State Denied group, Figure 9 shows that there is a clear difference in the share newly taking action (top panel) and currently holding modules in the corresponding statuses (bottom panel) for IAs and CNC-Hardships. Certified taxpayers are more likely to take these actions, and to remain in these statuses over time. There appears to be a small difference in OICs, but no apparent difference in bankruptcies. 
Figure 9: RCT analysis, comparison only by SSN groups, four actions leading to decertification

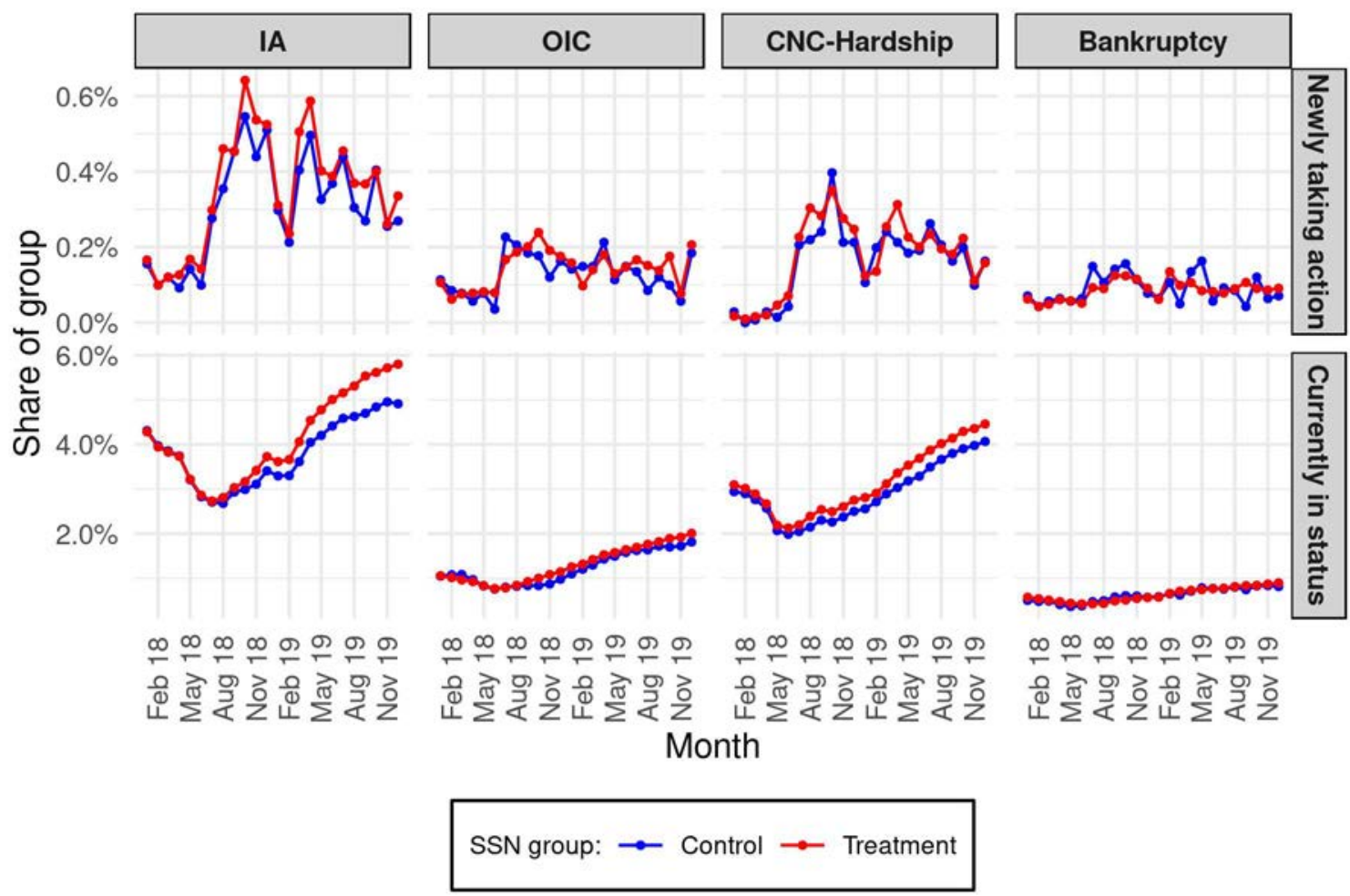

\begin{abstract}
Notes: This figure compares the share newly taking each action (top panel) or currently in a given status (bottom panel) for taxpayers who by SSN were assigned to treatment or control groups during the passport program rollout. All of the treatment group was certified, while approximately $20 \%$ of the control group migrated into treatment during the twelve-month RCT phase. The difference between the two groups thus reveals the effect of certification.
\end{abstract}

Figure 10 shows that, unlike what was observed above for the State Denied group, there is no apparent difference in the share newly resolving in full (i.e., having their total balance go to zero, by payment, abatement, or other means) or the cumulative share that has fully resolved over time. This may reflect the fact that the State Department denial is affecting a group of taxpayers who had demonstrated their interest in holding a passport, while the certification treatment here is affecting a much broader group of taxpayers with more varied interest in passport-holding. 
Figure 10: RCT analysis, comparison only by SSN groups, full resolution

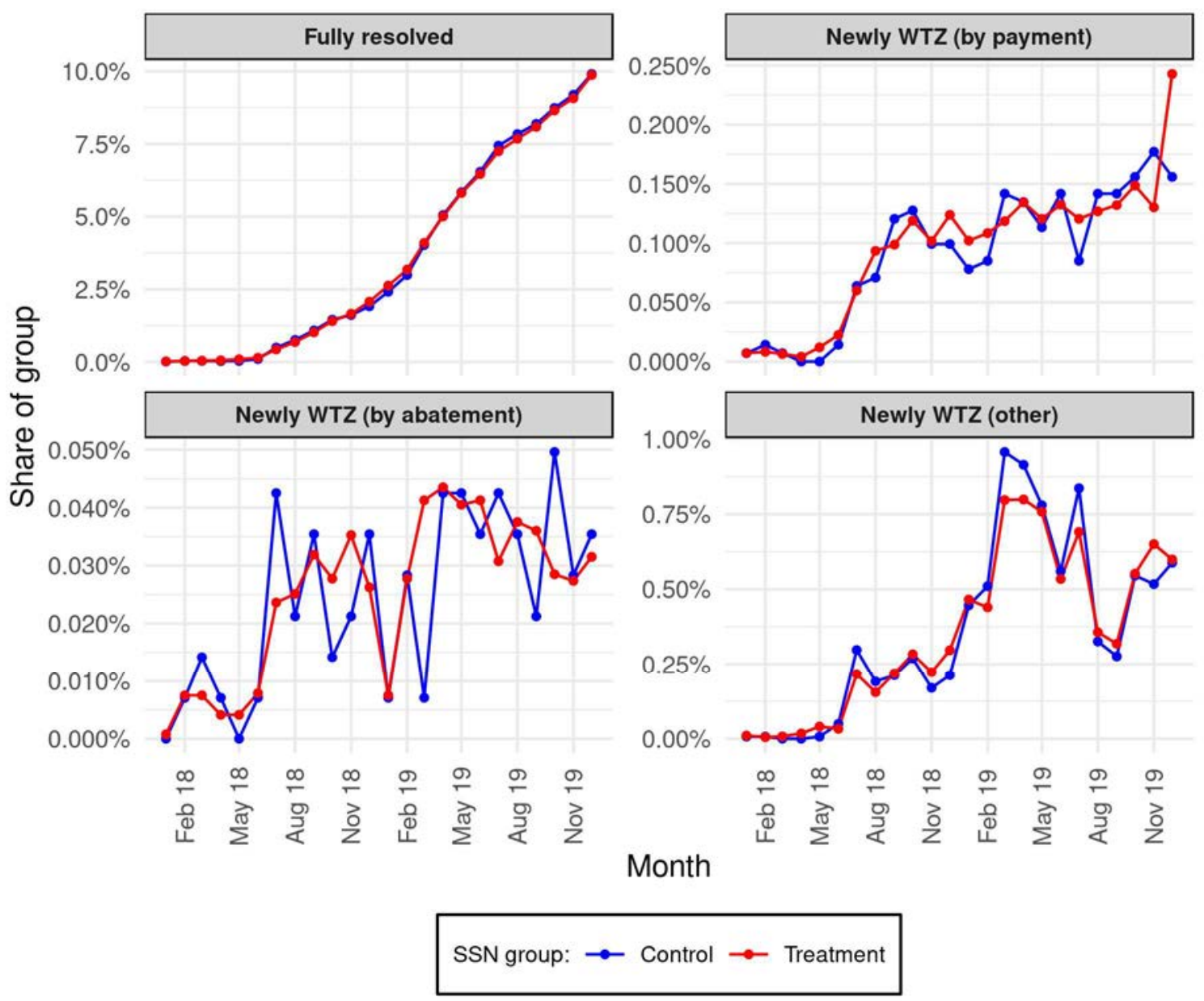

Notes: This figure compares treatment and control taxpayers by the share making a positive net payment, the cumulative share that has fully resolved over time, and the share newly having balance go to zero by payment or by other means.

Because of the treatment migration, we cannot simply add up the estimated cumulative difference between what we have thus far labelled the treatment and control groups. To obtain estimates of the causal effect of certification, we follow Angrist (2005) and apply an instrumental variables approach. The RCT-style implementation happened from the beginning of the program, in February, 2018, through February, 2019. We collapse the monthly variation in certification into a single dummy that equals 1 if a taxpayer was certified during this RCT phase, and 0 otherwise. The sample of included taxpayers includes all those who are either certified or held out in the control group, during the RCT phase. For each of these taxpayers, we define the following: 
- $Y_{i}=$ outcome for individual $i$ (e.g., change in balance)

- $D_{i}=$ treatment dummy, 1 if individual $i$ is certified during RCT phase, 0 otherwise

- $Z_{i}=$ instrument dummy, 1 if individual $i$ has a treatment SSN; 0 otherwise

We wish to estimate the following structural equation:

$$
Y_{i}=X_{i}^{\prime} \beta+\alpha D_{i}+\epsilon_{i}
$$

To account for treatment migration, we begin by estimating the following first stage:

$$
D_{i}=X_{i}^{\prime} \pi_{0}+\pi_{1} Z_{i}+\eta_{i}
$$

The reduced form, or second stage is:

$$
\begin{gathered}
Y_{i}=X_{i}^{\prime} \beta+\alpha\left[X_{i}^{\prime} \pi_{0}+\pi_{1} Z_{i}+\eta_{i}\right]+\epsilon_{i} \\
=X_{i}^{\prime} \delta_{0}+\delta_{1} Z_{i}+v_{i},
\end{gathered}
$$

allowing us to recover the causal effect of certification as follows:

$$
\alpha=\delta_{1} / \pi_{1}
$$

This approach satisfies the assumptions necessary for instrumental variables: within this population, (1) SSN is correlated with certification and (2) SSN only affects outcomes through its effect on certification.

Turning to the estimation itself, we first apply a few restrictions to the dataset. ${ }^{15}$ To exclude outliers, we filter the dataset based on December 2017 characteristics (unaffected by the passport program rollout). Specifically, we exclude taxpayers with a total assessed balance due of more than $\$ 1$ million, with a maximum module age (i.e., the age of their oldest tax-year-debt) more than 12 years, and those showing extreme numbers of modules. ${ }^{16}$ Consistent with previous research on tax debt collection, we include a number of covariates based on December 2017 balances: total assessed balance, maximum module age, the share of the total balance older than 9 years ${ }^{17}$, an indicator that the taxpayer had unfiled returns for at least one prior tax year, and the

\footnotetext{
${ }^{15}$ We test the sensitivity of our results to these restrictions and find little difference when adjusting them. Figure 17 in the Appendix shows the coefficient estimates under alternative data filters.

${ }^{16}$ We distinguish between Form 941 modules (Trust Fund Recovery Penalties assessed on a corporate officer for unpaid Form 941 liabilities, which are quarterly) and all other modules (which are annual). In our main specification, we exclude those taxpayers with more than 10 annual modules, or more than 40 quarterly modules.

${ }^{17}$ This allows us to control for the fact that the statute of limitations on most tax debt is 10 years. In some cases this means that a taxpayer's total balance due can fall due to the time limit being reached, and not because of action they have taken.
} 
number of existing modules with balance due. We also include dummy variables for the source of assessment (telling us about how the debt balance started, e.g., nonfiling, nonpayment, audit, etc.), status (telling us where the case is currently assigned in the collection process: currently assigned to field Revenue Officers or the Automated Collection System, inventories that are awaiting assignment, and inactive inventories), and taxpayer income type (three dummies indicating that the majority of income comes from wages, from Schedule $\mathrm{C}$ income, or from interest, dividends, and capital gains; with those with the majority of income from other sources as the excluded dummy). Table 11 in the Appendix presents summary statistics for the data used in the main RCT analysis.

We test the effect of certification on a number of outcomes as of December 2019, thus allowing several months for behavior to be affected. As above for the State Denied group, we examine a number of binary actions that lead to decertification: IAs, OICs, CNC-Hardships, and Bankruptcies, as well as full resolution (i.e., having total assessed balance go to zero, by payment or by abatement). For each of these, we study the effect on taking the action, as well as taking the action, getting decertified, and remaining uncertified as of December 2019. ${ }^{18}$

The results for the outcome of newly taking various decertification actions are shown in Table 4 . Consistent with the graphs above, we find that certification, instrumented using SSN, leads to increased activity by taxpayers in IAs, OICs, and CNC-Hardship designations. We do not find a significant effect on bankruptcies, nor for full resolution, either by payment or by abatement. These results suggest that certification does have a positive effect on compliance, but perhaps not in the way that a casual observer might expect (i.e., by leading taxpayers to pay their balances in full).

\footnotetext{
${ }^{18}$ We test the sensitivity of the results to our choice of end month and find little difference when choosing earlier end months. Figure 18 in the Appendix shows the coefficient estimates for the range of end months from March 2019 to December 2019. We do not include outcomes in 2020 for two reasons. First, the rollout of enhanced programming for complex debt certification in early 2020 resulted in many taxpayers getting newly certified or recertified, which especially affects our estimates conditional on remaining uncertified. Second, and more importantly, the COVID-19 pandemic led to the pausing of certifications in April 2020, and likely affected taxpayer behavior as well.
} 
Table 4: RCT IV analysis, results for newly taking various decertification actions

\begin{tabular}{|c|c|c|c|c|c|c|c|}
\hline & \multicolumn{4}{|c|}{ Taking new action any time Mar '18-Dec '19 } & \multicolumn{2}{|c|}{ Fully resolved as of Dec '19 } & \multirow{2}{*}{$\begin{array}{l}\text { Any of six } \\
\text { listed } \\
\text { actions } \\
\text { (7) }\end{array}$} \\
\hline & $\begin{array}{l}\mathrm{IA} \\
(1)\end{array}$ & $\begin{array}{l}\text { OIC } \\
(2)\end{array}$ & $\begin{array}{l}\text { CNC } \\
(3)\end{array}$ & $\begin{array}{l}\text { Bankruptcy } \\
\text { (4) }\end{array}$ & $\begin{array}{l}\text { By payment } \\
\text { (5) }\end{array}$ & $\begin{array}{c}\text { By abatement } \\
\text { (6) }\end{array}$ & \\
\hline Certified & $\begin{array}{l}\mathbf{0 . 0 1 3 1} \\
(0.0026)\end{array}$ & $\begin{array}{l}\mathbf{0 . 0 0 2 9} \\
(0.0017)\end{array}$ & $\begin{array}{l}\mathbf{0 . 0 0 4 9} \\
(0.0020)\end{array}$ & $\begin{array}{l}-0.0004 \\
(0.0014)\end{array}$ & $\begin{array}{l}\mathbf{0 . 0 0 1 6} \\
(0.0013)\end{array}$ & $\begin{array}{c}0.001 \\
(0.0009)\end{array}$ & $\begin{array}{l}\mathbf{0 . 0 2 0 5} \\
(0.0037)\end{array}$ \\
\hline \multicolumn{8}{|c|}{ Covariates as of Dec '17: } \\
\hline $\begin{array}{l}\text { Assessed balance } \\
(\$ M)\end{array}$ & $\begin{array}{l}-0.0504 \\
(0.0035)\end{array}$ & $\begin{array}{l}0.0209 \\
(0.0028)\end{array}$ & $\begin{array}{l}-0.0138 \\
(0.0031)\end{array}$ & $\begin{array}{l}0.0058 \\
(0.0021)\end{array}$ & $\begin{array}{l}-0.0118 \\
(0.0016)\end{array}$ & $\begin{array}{l}0.0139 \\
(0.0016)\end{array}$ & $\begin{array}{l}-0.0239 \\
(0.0054)\end{array}$ \\
\hline $\begin{array}{l}\text { Max module age } \\
\text { (yrs) }\end{array}$ & $\begin{array}{l}-0.0086 \\
(0.0002)\end{array}$ & $\begin{array}{l}-0.002 \\
(0.0001)\end{array}$ & $\begin{array}{c}-0.00001 \\
(0.0002)\end{array}$ & $\begin{array}{l}-0.0006 \\
(0.0001)\end{array}$ & $\begin{array}{l}-0.0035 \\
(0.0001)\end{array}$ & $\begin{array}{l}-0.0022 \\
(0.0001)\end{array}$ & $\begin{array}{l}-0.0158 \\
(0.0003)\end{array}$ \\
\hline $\begin{array}{l}\text { Share } A B>9 \text { yrs } \\
(\%)\end{array}$ & $\begin{array}{c}0.006 \\
(0.0020)\end{array}$ & $\begin{array}{l}-0.0097 \\
(0.0012)\end{array}$ & $\begin{array}{l}-0.0074 \\
(0.0018)\end{array}$ & $\begin{array}{l}-0.0018 \\
(0.0012)\end{array}$ & $\begin{array}{l}0.0042 \\
(0.0008)\end{array}$ & $\begin{array}{l}0.0027 \\
(0.0006)\end{array}$ & $\begin{array}{l}-0.0049 \\
(0.0030)\end{array}$ \\
\hline $\begin{array}{l}\text { Unfiled returns } \\
(1 / 0)\end{array}$ & $\begin{array}{l}-0.0184 \\
(0.0010)\end{array}$ & $\begin{array}{l}-0.0081 \\
(0.0006)\end{array}$ & $\begin{array}{l}-0.0063 \\
(0.0009)\end{array}$ & $\begin{array}{l}-0.0028 \\
(0.0005)\end{array}$ & $\begin{array}{l}-0.003 \\
(0.0005)\end{array}$ & $\begin{array}{l}-0.0019 \\
(0.0005)\end{array}$ & $\begin{array}{l}-0.037 \\
(0.0016)\end{array}$ \\
\hline $\begin{array}{l}\text { Modules } \\
\text { (\# of non-Form 941) }\end{array}$ & $\begin{array}{l}0.0051 \\
(0.0003)\end{array}$ & $\begin{array}{l}0.0035 \\
(0.0002)\end{array}$ & $\begin{array}{l}0.0015 \\
(0.0002)\end{array}$ & $\begin{array}{l}0.0008 \\
(0.0001)\end{array}$ & $\begin{array}{l}-0.002 \\
(0.0001)\end{array}$ & $\begin{array}{l}-0.0013 \\
(0.0001)\end{array}$ & $\begin{array}{c}0.007 \\
(0.0004)\end{array}$ \\
\hline $\begin{array}{l}\text { Modules } \\
\text { (\# of Form 941) }\end{array}$ & $\begin{array}{l}-0.0009 \\
(0.0002)\end{array}$ & $\begin{array}{l}0.0017 \\
(0.0002)\end{array}$ & $\begin{array}{l}0.0026 \\
(0.0002)\end{array}$ & $\begin{array}{l}0.0009 \\
(0.0001)\end{array}$ & $\begin{array}{l}-0.0012 \\
(0.0001)\end{array}$ & $\begin{array}{l}-0.0006 \\
(0.0001)\end{array}$ & $\begin{array}{l}0.0023 \\
(0.0004)\end{array}$ \\
\hline Constant & $\begin{array}{l}0.1613 \\
(0.0035)\end{array}$ & $\begin{array}{l}0.0387 \\
(0.0023)\end{array}$ & $\begin{array}{c}0.042 \\
(0.0026)\end{array}$ & $\begin{array}{l}0.0283 \\
(0.0018)\end{array}$ & $\begin{array}{l}0.0481 \\
(0.0018)\end{array}$ & $\begin{array}{c}0.0284 \\
(0.0013)\end{array}$ & $\begin{array}{c}0.3182 \\
(0.0049)\end{array}$ \\
\hline Income Dummies & Yes & Yes & Yes & Yes & Yes & Yes & Yes \\
\hline SOA Dummies & Yes & Yes & Yes & Yes & Yes & Yes & Yes \\
\hline Status Dummies & Yes & Yes & Yes & Yes & Yes & Yes & Yes \\
\hline Observations & 266,890 & 266,890 & 266,890 & 266,890 & 266,890 & 266,890 & 266,890 \\
\hline Adjusted $\mathrm{R}^{2}$ & 0.075 & 0.022 & 0.020 & 0.010 & 0.021 & 0.012 & 0.124 \\
\hline Mean dep. var. & 0.076 & 0.028 & 0.040 & 0.017 & 0.016 & 0.008 & 0.172 \\
\hline
\end{tabular}

Notes: heteroskedasticity-robust standard errors in parentheses.

One concern with the passport program is that a taxpayer, once certified, could attempt to "game the system" by taking action which leads to decertification, but only temporarily. For example, a taxpayer could work to get decertified, use the time when initially decertified to make any necessary passport-related requests, and subsequently renege on any commitments that led to decertification. To test whether certification leads to more long-lasting compliance, we pair the outcome of newly taking each decertification action with the restriction that a taxpayer remain uncertified at the end of our observation window, in December 2019 - that is, we test whether 
certification leads taxpayers not just to take action to get decertified but also to remain uncertified. The results of these tests suggest that there is indeed a persistent effect on compliance; certification leads to higher probability of new and maintained IAs and CNC designations (see Table 12 in the Appendix). As further support for the certification effects being persistent, we observe that nearly all certified taxpayers who enter into a pending IA status ultimately convert that into an approved IA. Also note that the program is designed to discourage this sort of gaming behavior; a taxpayer who reneges on a prior agreement would be subsequently reidentified as eligible for certification, and fall back into certification.

Finally, we consider several balance-related outcomes. Given the notched structure of certification, we do not expect a strong response of small payments. Once a taxpayer is certified, they must pay off or otherwise resolve all of their certified debt; merely paying off an amount to get below the certification threshold of $\$ 54,000$ (lower in earlier years) does not lead to decertification. Nevertheless, we test the effect of certification on payments (both in dollars and as a share of December 2017 assessed balance), and on changes in balance, changes in log balance, and binary variables indicating a fall in balance or increase in balance. The results for the balance-related outcomes are shown below in Table 5. We do find a small positive effect on the probability of payment, though this likely reflects, at least in part, the new IAs we saw before. Consistent with our expectations, we do not find a strong effect of certification on payments on average when measured in dollars, though we do find a marginally significant effect on payments as a share of starting balance, suggesting that certification causes 0.34 percentage points more to be paid off, on average, over the two years leading up to December 2019. We similarly find no significant effect on changes in balance, though interestingly we do find that certification makes it less likely that a taxpayer will have a fall in balance, and more likely that they have an increase in balance. One explanation for this is that the actions that certification induces - IAs, OICs, and CNCs - require a taxpayer to be current on all their current and prior tax filings. Certified taxpayers induced to take compliance actions may thus have filed returns resulting in increased assessed balances in order to meet the requirements for subsequent compliance actions.

To test for this, we add several combination outcomes: taking an action (IA, OIC, or CNC) and adding new modules. Similarly, we add the combos of not taking action and adding new 
modules, or not taking action and increasing assessed balance. The results provide some support for the hypothesis that the increase in assessed balance effect is a side effect of certification driving IA, OIC, and CNC action: the positive effect of certification on adding new modules is only found among those also taking compliance actions. Table 13 in the Appendix reports the full results of this test.

Table 5: RCT IV analysis, results for balance-related outcomes

\begin{tabular}{|c|c|c|c|c|c|c|c|}
\hline & \multicolumn{3}{|c|}{ Cumulative payments } & \multicolumn{4}{|c|}{ Assessed balance, Dec '19 vs. Dec '17 } \\
\hline & $\begin{array}{c}\text { Made } \\
\text { payment } \\
\text { (1) }\end{array}$ & $\begin{array}{l}\text { Amount } \\
\text { (\$K) } \\
(1)\end{array}$ & $\begin{array}{c}\text { Share } \\
\text { (of Dec '17 AB) } \\
\text { (2) }\end{array}$ & $\begin{array}{c}d(\text { bal) }(\$ K) \\
(3)\end{array}$ & $\begin{array}{c}d(\log b a l+1) \\
(4)\end{array}$ & $\begin{array}{c}\text { 1(Decrease } \\
\text { in } A B) \\
(5)\end{array}$ & $\begin{array}{c}1 \text { (Increase } \\
\text { in } A B) \\
(6)\end{array}$ \\
\hline Certified & $\begin{array}{l}0.0193 \\
(0.0050)\end{array}$ & $\begin{array}{l}0.1274 \\
(0.5893)\end{array}$ & $\begin{array}{c}0.0034 \\
(0.0021)\end{array}$ & $\begin{array}{l}0.9946 \\
(1.2138)\end{array}$ & $\begin{array}{c}\mathbf{0 . 0 1 2 1} \\
(0.0154)\end{array}$ & $\begin{array}{l}-0.0108 \\
(0.0050)\end{array}$ & $\begin{array}{l}0.0214 \\
(0.0048)\end{array}$ \\
\hline \multicolumn{8}{|c|}{ Covariates as of Dec '17: } \\
\hline $\begin{array}{l}\text { Assessed balance } \\
(\$ M)\end{array}$ & $\begin{array}{l}0.0733 \\
(0.0069)\end{array}$ & $\begin{array}{l}57.2689 \\
(2.4481)\end{array}$ & $\begin{array}{l}-0.057 \\
(0.0026)\end{array}$ & $\begin{array}{c}-165.1757 \\
(4.8166)\end{array}$ & $\begin{array}{l}-0.7703 \\
(0.0263)\end{array}$ & $\begin{array}{l}0.0643 \\
(0.0070)\end{array}$ & $\begin{array}{l}-0.0479 \\
(0.0066)\end{array}$ \\
\hline $\begin{array}{l}\text { Max module age } \\
\text { (yrs) }\end{array}$ & $\begin{array}{l}-0.0199 \\
(0.0004)\end{array}$ & $\begin{array}{l}-2.4287 \\
(0.0566)\end{array}$ & $\begin{array}{l}-0.0128 \\
(0.0002)\end{array}$ & $\begin{array}{l}-8.0908 \\
(0.1231)\end{array}$ & $\begin{array}{l}-0.1464 \\
(0.0015)\end{array}$ & $\begin{array}{l}0.0517 \\
(0.0004)\end{array}$ & $\begin{array}{l}-0.0501 \\
(0.0004)\end{array}$ \\
\hline $\begin{array}{l}\text { Share } A B>9 \text { yrs } \\
(\%)\end{array}$ & $\begin{array}{l}0.0151 \\
(0.0047)\end{array}$ & $\begin{array}{l}3.1728 \\
(0.3154)\end{array}$ & $\begin{array}{l}0.0156 \\
(0.0013)\end{array}$ & $\begin{array}{c}-86.0288 \\
(1.2793)\end{array}$ & $\begin{array}{l}-1.9004 \\
(0.0180)\end{array}$ & $\begin{array}{l}0.4531 \\
(0.0037)\end{array}$ & $\begin{array}{l}-0.2552 \\
(0.0035)\end{array}$ \\
\hline $\begin{array}{l}\text { Unfiled returns } \\
(1 / 0)\end{array}$ & $\begin{array}{l}-0.0386 \\
(0.0025)\end{array}$ & $\begin{array}{l}-2.2489 \\
(0.2118)\end{array}$ & $\begin{array}{l}-0.0066 \\
(0.0008)\end{array}$ & $\begin{array}{l}4.3581 \\
(0.7554)\end{array}$ & $\begin{array}{l}0.1465 \\
(0.0075)\end{array}$ & $\begin{array}{l}-0.0271 \\
(0.0023)\end{array}$ & $\begin{array}{l}0.0518 \\
(0.0023)\end{array}$ \\
\hline $\begin{array}{l}\text { Modules } \\
\text { (\# of non-Form 941) }\end{array}$ & $\begin{array}{c}0.0124 \\
(0.0005)\end{array}$ & $\begin{array}{l}-0.8404 \\
(0.0685)\end{array}$ & $\begin{array}{l}-0.0034 \\
(0.0002)\end{array}$ & $\begin{array}{l}4.0132 \\
(0.1413)\end{array}$ & $\begin{array}{l}0.1589 \\
(0.0016)\end{array}$ & $\begin{array}{l}-0.0135 \\
(0.0005)\end{array}$ & $\begin{array}{c}0.0256 \\
(0.0005)\end{array}$ \\
\hline $\begin{array}{l}\text { Modules } \\
\text { (\# of Form 941) }\end{array}$ & $\begin{array}{c}0.0088 \\
(0.0004)\end{array}$ & $\begin{array}{l}-1.0601 \\
(0.0471)\end{array}$ & $\begin{array}{l}-0.0045 \\
(0.0002)\end{array}$ & $\begin{array}{c}1.6792 \\
(0.1187)\end{array}$ & $\begin{array}{c}0.05 \\
(0.0012)\end{array}$ & $\begin{array}{l}-0.0022 \\
(0.0004)\end{array}$ & $\begin{array}{l}0.0076 \\
(0.0004)\end{array}$ \\
\hline Constant & $\begin{array}{c}0.5454 \\
(0.0061)\end{array}$ & $\begin{array}{c}25.0678 \\
(0.7868)\end{array}$ & $\begin{array}{c}0.2012 \\
(0.0028)\end{array}$ & $\begin{array}{l}41.8917 \\
(1.7023)\end{array}$ & $\begin{array}{l}-0.2329 \\
(0.0193)\end{array}$ & $\begin{array}{l}0.2166 \\
(0.0063)\end{array}$ & $\begin{array}{l}0.5715 \\
(0.0060)\end{array}$ \\
\hline Income Dummies & Yes & Yes & Yes & Yes & Yes & Yes & Yes \\
\hline SOA Dummies & Yes & Yes & Yes & Yes & Yes & Yes & Yes \\
\hline Status Dummies & Yes & Yes & Yes & Yes & Yes & Yes & Yes \\
\hline Observations & 266,890 & 266,890 & 266,890 & 266,890 & 266,890 & 266,890 & 266,890 \\
\hline Adjusted $\mathrm{R}^{2}$ & 0.169 & 0.073 & 0.124 & 0.115 & 0.218 & 0.165 & 0.208 \\
\hline Mean dep. var. & 0.4770 & 12.13 & 0.0780 & -14.8190 & -0.6180 & 0.4570 & 0.4200 \\
\hline
\end{tabular}

Notes: heteroskedasticity-robust standard errors in parentheses.

The results of the RCT analysis suggest that there is indeed a positive effect of passport certification on tax compliance behavior, though somewhat smaller than the effect seen above in the State Denied analysis. This is to be expected, as the taxpayers in the State Denied group have 
made a passport-related request to the State Department and thus place some value on holding a passport. The treated taxpayers in the broader RCT analysis, on the other hand, include a mix of taxpayers, some of whom may not place much value on holding a passport, or may not anticipate needing to request one from the State Department in the near future. Furthermore, the results we find in the RCT analysis could be considered a lower bound on the effect of certification, as it is possible some of the control group taxpayers were aware that they were eligible for certification and acted in response to this. Although most of those in the control group were not certified, some may still have taken action to avoid the risk of future certification, which would provide a downward bias to the difference between the treatment and control groups as a causal estimate of the treatment. We thus consider further analysis of both the direct effects of certification and the indirect effects potential certifications to address this potential bias.

\subsection{Heterogeneity of the effect of certification}

Having considered the effect of certification overall, we now turn to several analyses which develop a more nuanced understanding of the effects of certification. We begin by noting that there may be a difference in program response for taxpayers with pre-existing debt relative to taxpayers with new debt. Recall that there was a large group of taxpayers with significant balances that would have been eligible for certification for years prior to 2018, if the program had been in place during those years. These taxpayers comprise the "pre-existing" delinquent taxpayers, distinct from the "new" delinquent taxpayers that become newly eligible once the program begins. ${ }^{19}$ Understanding whether the response in these two groups differs is important because it is conceivable that the new taxpayers offer the best evidence for what effect the passport program will have going forward.

We begin with a graphical comparison, taking the same approach as above for the overall effect of certification, but now splitting the samples into preexisting and new taxpayers. There are clear differences in the base level of activity for the various actions we study, as shown in Figure 11. In general, the new cases are more likely to take action; this is to be expected, as these cases are

\footnotetext{
${ }^{19}$ We define as "preexisting" observations those that had an eligible balance above \$50,000 in December 2016 and that did not accrue additional modules between December 2016 and March 2018, when certifications began. These individuals would have been certified had the program been in operation in December 2016, but as it was not, they were not certified until the rollout began. We define the remaining cases as "new" cases - these are cases that either had new modules accruing between December 2016 and March 2018, or did not have a sufficiently high eligible balance in December 2016 to warrant certification, but had such a balance during the passport program rollout.
} 
being certified during the normal progression of the collection process. Thus, the certification is coming immediately after the triggering events for eligibility. The pre-existing cases are being certified well after the triggering events and in many instances after other actions have taken and the debt was not resolved.

Comparing the rate of activity between treatment and control SSNs, within the pre-existing and new groups, suggests that there may be differences in the treatment effect of certification for the two groups. We test for this using the same regression framework as above, now splitting the sample into the pre-existing and new cases. The results are shown in Table 6. Certification has a significant effect on the probability of new IAs and of any resolution, for both groups. The significant effect for new OICs and new CNCs is found only in the pre-existing cases. This is consistent with the notion that for the pre-existing cases, it is more likely that the only viable resolution available is an administrative resolution like and OIC or CNC. The new cases are more likely to have the ability to pay and not be eligible for OIC or $\mathrm{CNC}$ resolutions. 
Figure 11: RCT analysis, comparison only by SSN groups, split by Pre-existing and New cases

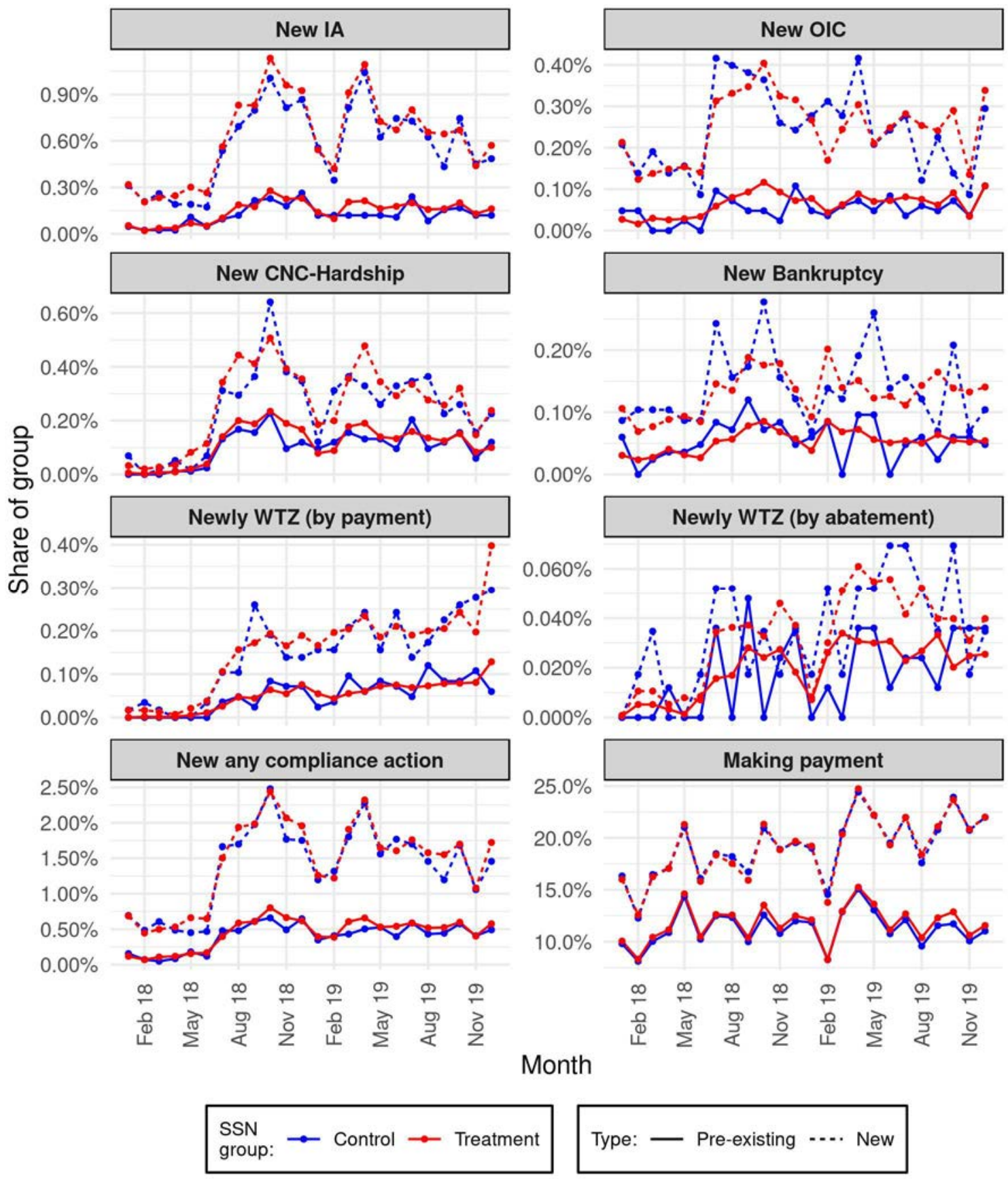

Notes: This figure compares treatment and control taxpayers by the share newly taking any of the binary actions leading to decertification, splitting the sample into taxpayers categorized as "preexisting" or "new". 
Table 6: RCT IV analysis, results for separate analysis of Pre-existing and New cases

\begin{tabular}{|c|c|c|c|c|c|c|c|}
\hline & \multicolumn{4}{|c|}{ Taking new action any time Mar '18-Dec '19 } & \multicolumn{2}{|c|}{ Fully resolved as of Dec '19 } & \multirow{2}{*}{$\begin{array}{l}\text { Any of six } \\
\text { listed } \\
\text { actions } \\
\text { (7) }\end{array}$} \\
\hline & $\begin{array}{l}\text { IA } \\
(1)\end{array}$ & $\begin{array}{l}\text { OIC } \\
(2)\end{array}$ & $\begin{array}{l}\text { CNC } \\
\text { (3) }\end{array}$ & $\begin{array}{l}\text { Bankruptcy } \\
\text { (4) }\end{array}$ & $\begin{array}{l}\text { By payment } \\
\text { (5) }\end{array}$ & $\begin{array}{c}\text { By abatement } \\
\text { (6) }\end{array}$ & \\
\hline \multicolumn{8}{|c|}{ Panel A: Pre-existing debt } \\
\hline Certified & $\begin{array}{l}\mathbf{0 . 0 0 5 5} \\
(0.0019)\end{array}$ & $\begin{array}{c}\mathbf{0 . 0 0 3} \\
(0.0012)\end{array}$ & $\begin{array}{l}\mathbf{0 . 0 0 4 2} \\
(0.0018)\end{array}$ & $\begin{array}{l}\mathbf{0 . 0 0 0 6} \\
(0.0012)\end{array}$ & $\begin{array}{l}-0.0003 \\
(0.0011)\end{array}$ & $\begin{array}{c}\mathbf{0 . 0 0 1} \\
(0.0009)\end{array}$ & $\begin{array}{l}\mathbf{0 . 0 1 3 6} \\
(0.0031)\end{array}$ \\
\hline Mean dep. var. & 0.0320 & 0.0130 & 0.0260 & 0.0110 & 0.0080 & 0.0060 & 0.0910 \\
\hline Observations & 155,317 & 155,317 & 155,317 & 155,317 & 155,317 & 155,317 & 155,317 \\
\hline Adjusted $\mathrm{R}^{2}$ & 0.039 & 0.013 & 0.016 & 0.008 & 0.011 & 0.009 & 0.071 \\
\hline \multicolumn{8}{|l|}{ Panel B: New debt } \\
\hline Certified & $\begin{array}{l}\mathbf{0 . 0 2 7 1} \\
(0.0073)\end{array}$ & $\begin{array}{l}\mathbf{0 . 0 0 1 8} \\
(0.0049)\end{array}$ & $\begin{array}{l}\mathbf{0 . 0 0 5 6} \\
(0.0052)\end{array}$ & $\begin{array}{c}-0.003 \\
(0.0038)\end{array}$ & $\begin{array}{l}\mathbf{0 . 0 0 5 5} \\
(0.0034)\end{array}$ & $\begin{array}{l}0.0009 \\
(0.0023)\end{array}$ & $\begin{array}{l}\mathbf{0 . 0 3 1 1} \\
(0.0097)\end{array}$ \\
\hline Mean dep. var. & 0.1370 & 0.0490 & 0.0580 & 0.0260 & 0.0270 & 0.0110 & 0.2860 \\
\hline Observations & 111,573 & 111,573 & 111,573 & 111,573 & 111,573 & 111,573 & 111,573 \\
\hline Adjusted $\mathrm{R}^{2}$ & 0.059 & 0.016 & 0.017 & 0.007 & 0.020 & 0.017 & 0.088 \\
\hline Dec '17 Covariates & Yes & Yes & Yes & Yes & Yes & Yes & Yes \\
\hline Income Dummies & Yes & Yes & Yes & Yes & Yes & Yes & Yes \\
\hline SOA Dummies & Yes & Yes & Yes & Yes & Yes & Yes & Yes \\
\hline Status Dummies & Yes & Yes & Yes & Yes & Yes & Yes & Yes \\
\hline
\end{tabular}

Notes: heteroskedasticity-robust standard errors in parentheses.

We next examine whether the effect of certification is stronger among taxpayers who are more likely to have or want passports. Although we cannot determine who is a passport holder directly, at least for those taxpayers with recent tax filings we can observe taxpayer characteristics that are correlated with passport holding (based on an analysis of state-level passport holding in Florida (2011)). About one-third of the taxpayers in our main specification do not have recent tax filings and so are excluded from these tests. However, non-filing is not randomly distributed. Among the new cases, $88 \%$ have filings, while only $54 \%$ of preexisting cases have filings. This means that, compared to the main results above, these heterogeneity tests are weighted more towards the effect on new cases. We investigate four characteristics that are correlated with passport holding: (1) income: higher-income individuals are more likely to hold passports; (2) age: older individuals are more likely to hold passports; (3) location: border state residents are more likely 
to hold passports; and (4) tax filing markers that indicate foreign activity. ${ }^{20}$ As above, we start by comparing behavior graphically, splitting by treatment or control SSN and each of the passport proxy characteristics. We then incorporate these proxy characteristics into our regression analysis. Figure 12 compares the share of treatment and control groups newly taking any decertification action each month, splitting by the four different proxies: total positive income, age, border/non-border state, and foreign tax markers. We see clear differences in the activity levels when splitting by income (top-left panel) and by foreign tax markers (bottom-right panel).

Figure 12: RCT analysis, comparison only by SSN groups, heterogeneity in treatment effect

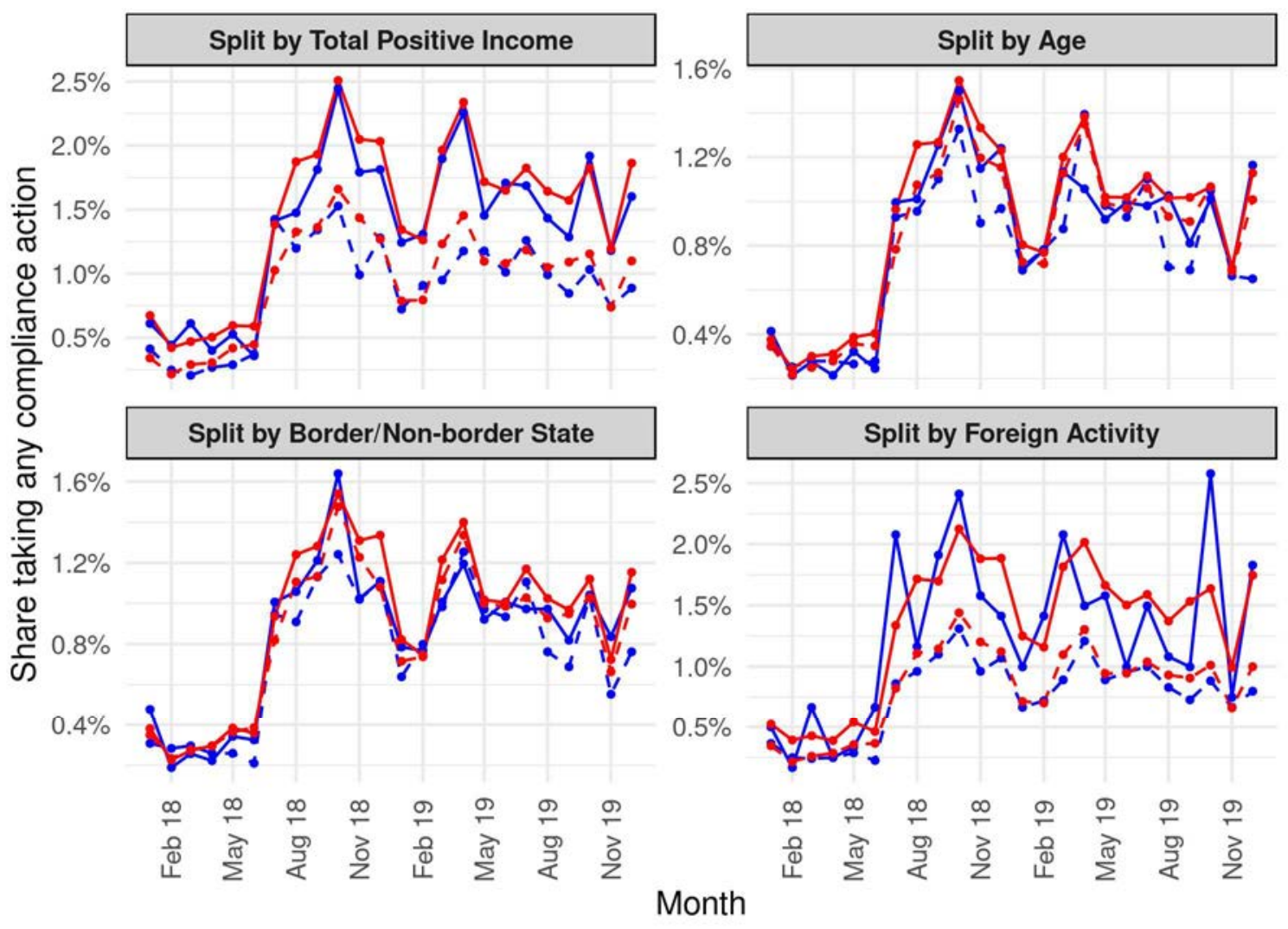

$$
\begin{array}{l||l}
- \text { Control } & - \text { Above median TPI }- \text { Above median age }- \text { Border state } \quad \text { Foreign activity } \\
\text { - Treatment } & -- \text { Below median TPI }- \text { - Below median age }- \text { - Non-border state }- \text { - No foreign activity }
\end{array}
$$

\footnotetext{
${ }^{20}$ Specifically, we identify foreign activity as any of the following: claiming the Foreign Tax Credit or the Foreign Earned Income Exclusion; filing from a foreign address; or filing a Foreign Bank Account Report (FBAR), for any tax year prior to and including 2017.
} 
Notes: This figure compares treatment and control taxpayers by the share newly taking any of the binary actions leading to decertification, splitting on four proxies for passport holding: income, age, border/non-border state, and tax filing markers that indicate foreign activity.

Adding these treatment intensity proxies to the IV framework requires adding the characteristics as well as interactions of the characteristics with the certification dummy and with the SSN dummy. We use the characteristic X SSN interaction dummy as an instrument for the characteristic X certification dummy. Table 7 presents the results when testing the effect of certification and including these interactions on the binary outcomes of newly taking various actions (the same outcomes tested above in Table 4). Consistent with the graphs, we see a significant differential effect on the combined action outcome for the income interaction, but not for age, residing in a border state, or foreign activity. This appears to be driven by a stronger effect on IAs and full resolution by payment for those with higher incomes. ${ }^{21}$ The marginally significant interaction effects for foreign tax activity on new OICs and new abatement could be explained by the relative sophistication and use of tax preparers by those with foreign activity, relative to those without.

\footnotetext{
${ }^{21}$ The stronger response among higher-income taxpayers may also reflect a greater ability-to-pay, especially when considering the new IA and full resolution outcomes. In the State Denied analysis above, in which all individuals had demonstrated a demand for passports, we found differences in response by income supportive of the ability-topay explanation: new IAs and full resolutions were more common for above-median income taxpayers, while new OICs and CNC-Hardship designations were more common for below-median income taxpayers.
} 
Table 7: RCT treatment intensity regression results

\begin{tabular}{|c|c|c|c|c|c|c|c|}
\hline & \multicolumn{4}{|c|}{ Taking new action any time Mar '18-Dec '19 } & \multicolumn{2}{|c|}{ Fully resolved as of Dec '19 } & \multirow{2}{*}{$\begin{array}{l}\text { Any of six } \\
\text { listed } \\
\text { actions } \\
\text { (7) }\end{array}$} \\
\hline & $\begin{array}{l}\mathrm{IA} \\
(1)\end{array}$ & $\begin{array}{l}\text { OIC } \\
(2)\end{array}$ & $\begin{array}{l}\text { CNC } \\
(3)\end{array}$ & $\begin{array}{c}\text { Bankruptcy } \\
\text { (4) }\end{array}$ & $\begin{array}{c}\text { By payment } \\
\text { (5) }\end{array}$ & $\begin{array}{c}\text { By abatement } \\
\text { (6) }\end{array}$ & \\
\hline Certified & $\begin{array}{l}0.0131 \\
(0.0063)\end{array}$ & $\begin{array}{c}0.0082 \\
(0.0045)\end{array}$ & $\begin{array}{l}0.0111 \\
(0.0055)\end{array}$ & $\begin{array}{l}-0.0038 \\
(0.0042)\end{array}$ & $\begin{array}{l}-0.0031 \\
(0.0027)\end{array}$ & $\begin{array}{c}0.0001 \\
(0.0024)\end{array}$ & $\begin{array}{c}0.0231 \\
(0.0096)\end{array}$ \\
\hline TPI > median TPI & $\begin{array}{l}0.0429 \\
(0.0083)\end{array}$ & $\begin{array}{l}-0.0002 \\
(0.0055)\end{array}$ & $\begin{array}{c}-0.024 \\
(0.0061)\end{array}$ & $\begin{array}{l}-0.0061 \\
(0.0045)\end{array}$ & $\begin{array}{c}0.0092 \\
(0.0040)\end{array}$ & $\begin{array}{l}-0.0027 \\
(0.0026)\end{array}$ & $\begin{array}{l}0.0218 \\
(0.0114)\end{array}$ \\
\hline Cert X TPI>median & $\begin{array}{c}0.0236 \\
(0.0085)\end{array}$ & $\begin{array}{l}-0.0052 \\
(0.0056)\end{array}$ & $\begin{array}{l}-0.0083 \\
(0.0063)\end{array}$ & $\begin{array}{l}0.0013 \\
(0.0046)\end{array}$ & $\begin{array}{c}0.0088 \\
(0.0041)\end{array}$ & $\begin{array}{c}0.0004 \\
(0.0027)\end{array}$ & $\begin{array}{c}0.0202 \\
(0.0117)\end{array}$ \\
\hline Age $>$ median age & $\begin{array}{c}0.005 \\
(0.0080)\end{array}$ & $\begin{array}{l}0.0026 \\
(0.0054)\end{array}$ & $\begin{array}{l}0.0165 \\
(0.0061)\end{array}$ & $\begin{array}{l}-0.0041 \\
(0.0044)\end{array}$ & $\begin{array}{l}0.0009 \\
(0.0038)\end{array}$ & $\begin{array}{c}-0.00001 \\
(0.0026)\end{array}$ & $\begin{array}{l}0.0201 \\
(0.0112)\end{array}$ \\
\hline Cert X Age>median & $\begin{array}{l}-0.0032 \\
(0.0082)\end{array}$ & $\begin{array}{l}-0.0016 \\
(0.0055)\end{array}$ & $\begin{array}{l}-0.0021 \\
(0.0063)\end{array}$ & $\begin{array}{c}0.0024 \\
(0.0045)\end{array}$ & $\begin{array}{c}0.0057 \\
(0.0039)\end{array}$ & $\begin{array}{c}0.0012 \\
(0.0027)\end{array}$ & $\begin{array}{c}0.0012 \\
(0.0115)\end{array}$ \\
\hline Border state & $\begin{array}{l}0.0064 \\
(0.0081)\end{array}$ & $\begin{array}{c}0.0025 \\
(0.0054)\end{array}$ & $\begin{array}{l}0.0013 \\
(0.0061)\end{array}$ & $\begin{array}{l}-0.0036 \\
(0.0044)\end{array}$ & $\begin{array}{c}0.0085 \\
(0.0040)\end{array}$ & $\begin{array}{c}0.0021 \\
(0.0027)\end{array}$ & $\begin{array}{c}0.0166 \\
(0.0113)\end{array}$ \\
\hline Cert X Border state & $\begin{array}{l}-0.0012 \\
(0.0083)\end{array}$ & $\begin{array}{c}0.004 \\
(0.0056)\end{array}$ & $\begin{array}{l}-0.0024 \\
(0.0063)\end{array}$ & $\begin{array}{l}-0.0005 \\
(0.0045)\end{array}$ & $\begin{array}{l}-0.0039 \\
(0.0041)\end{array}$ & $\begin{array}{l}-0.0003 \\
(0.0028)\end{array}$ & $\begin{array}{l}-0.0048 \\
(0.0116)\end{array}$ \\
\hline Foreign tax filings & $\begin{array}{l}0.0168 \\
(0.0171)\end{array}$ & $\begin{array}{l}0.0221 \\
(0.0118)\end{array}$ & $\begin{array}{l}-0.0045 \\
(0.0109)\end{array}$ & $\begin{array}{l}-0.0124 \\
(0.0072)\end{array}$ & $\begin{array}{c}0.0142 \\
(0.0103)\end{array}$ & $\begin{array}{l}-0.0045 \\
(0.0055)\end{array}$ & $\begin{array}{c}0.0358 \\
(0.0226)\end{array}$ \\
\hline Cert $\mathrm{X}$ Foreign tax & $\begin{array}{c}-0.008 \\
(0.0176)\end{array}$ & $\begin{array}{l}-0.0223 \\
(0.0120)\end{array}$ & $\begin{array}{c}0.0011 \\
(0.0112)\end{array}$ & $\begin{array}{c}0.0097 \\
(0.0074)\end{array}$ & $\begin{array}{c}0.0083 \\
(0.0106)\end{array}$ & $\begin{array}{c}0.0104 \\
(0.0057)\end{array}$ & $\begin{array}{l}-0.0047 \\
(0.0231)\end{array}$ \\
\hline Dec '17 Covariates & Yes & Yes & Yes & Yes & Yes & Yes & Yes \\
\hline Income Dummies & Yes & Yes & Yes & Yes & Yes & Yes & Yes \\
\hline SOA Dummies & Yes & Yes & Yes & Yes & Yes & Yes & Yes \\
\hline Status Dummies & Yes & Yes & Yes & Yes & Yes & Yes & Yes \\
\hline Observations & 179,813 & 179,813 & 179,813 & 179,813 & 179,813 & 179,813 & 179,813 \\
\hline Adjusted $\mathrm{R}^{2}$ & 0.064 & 0.014 & 0.020 & 0.006 & 0.025 & 0.016 & 0.084 \\
\hline Mean dep. var. & 0.1090 & 0.0410 & 0.0530 & 0.0240 & 0.0220 & 0.0100 & 0.2410 \\
\hline
\end{tabular}

Notes: heteroskedasticity-robust standard errors in parentheses.

To further explore the interaction of income with the effect of certification, we identify the quartiles of total positive income among all 2017 tax filings, and categorize our taxpayers into each of these. ${ }^{22}$ We then run the same interaction regressions as above, now using the TPI quartiles and their certification and SSN interactions. The results are shown in Table 8, and

\footnotetext{
${ }^{22}$ Our estimated quartile boundaries using a $1 \%$ random sample of filings are roughly $\$ 18,000, \$ 40,000$, and $\$ 82,000$.
} 
confirm that the certification effect is larger for those with higher income, concentrated in the top quartile of income. Figure 13 shows these results graphically, and Figure 19 in the Appendix shows the results when using deciles instead of quartiles, and the results are consistent. In general, we find that the effect of certification on actions that require some payment are higher for those with higher incomes (new IAs, and full resolution by payment). We also find that the effect on the probability of any resolution increases with income, likely driven by new IAs being a large component of the overall resolution effect.

Table 8: RCT IV analysis, results with Total Positive Income interactions

\begin{tabular}{|c|c|c|c|c|c|c|c|}
\hline & \multicolumn{4}{|c|}{ Taking new action any time Mar '18-Dec '19 } & \multicolumn{2}{|c|}{ Fully resolved as of Dec '19 } & \multirow{2}{*}{$\begin{array}{l}\text { Any of six } \\
\text { listed } \\
\text { actions } \\
\text { (7) }\end{array}$} \\
\hline & $\begin{array}{l}\mathrm{IA} \\
(1)\end{array}$ & $\begin{array}{l}\text { OIC } \\
(2)\end{array}$ & $\begin{array}{l}\text { CNC } \\
(3)\end{array}$ & $\begin{array}{c}\text { Bankruptcy } \\
\text { (4) }\end{array}$ & $\begin{array}{l}\text { By payment } \\
\text { (5) }\end{array}$ & $\begin{array}{c}\text { By abatement } \\
\text { (6) }\end{array}$ & \\
\hline Certified & $\begin{array}{l}0.0021 \\
(0.0058)\end{array}$ & $\begin{array}{l}0.0103 \\
(0.0048)\end{array}$ & $\begin{array}{c}0.011 \\
(0.0068)\end{array}$ & $\begin{array}{l}-0.0045 \\
(0.0046)\end{array}$ & $\begin{array}{c}-0.004 \\
(0.0032)\end{array}$ & $\begin{array}{c}0.0024 \\
(0.0032)\end{array}$ & $\begin{array}{c}0.0149 \\
(0.0105)\end{array}$ \\
\hline TPI in Q2 & $\begin{array}{l}-0.0019 \\
(0.0086)\end{array}$ & $\begin{array}{l}0.0113 \\
(0.0075)\end{array}$ & $\begin{array}{l}-0.0028 \\
(0.0096)\end{array}$ & $\begin{array}{c}-0.002 \\
(0.0065)\end{array}$ & $\begin{array}{l}0.0004 \\
(0.0044)\end{array}$ & $\begin{array}{l}0.0029 \\
(0.0045)\end{array}$ & $\begin{array}{c}0.0132 \\
(0.0153)\end{array}$ \\
\hline Cert X TPI in Q2 & $\begin{array}{c}0.014 \\
(0.0088)\end{array}$ & $\begin{array}{l}-0.0099 \\
(0.0078)\end{array}$ & $\begin{array}{c}0.0007 \\
(0.0099)\end{array}$ & $\begin{array}{c}0.0027 \\
(0.0067)\end{array}$ & $\begin{array}{c}0.0002 \\
(0.0045)\end{array}$ & $\begin{array}{l}-0.0033 \\
(0.0046)\end{array}$ & $\begin{array}{c}0.0006 \\
(0.0157)\end{array}$ \\
\hline TPI in Q3 & $\begin{array}{c}0.02 \\
(0.0094)\end{array}$ & $\begin{array}{l}0.0058 \\
(0.0071)\end{array}$ & $\begin{array}{l}-0.0027 \\
(0.0092)\end{array}$ & $\begin{array}{l}-0.0041 \\
(0.0062)\end{array}$ & $\begin{array}{l}0.0003 \\
(0.0044)\end{array}$ & $\begin{array}{c}0.001 \\
(0.0040)\end{array}$ & $\begin{array}{l}0.0218 \\
(0.0149)\end{array}$ \\
\hline Cert X TPI in Q3 & $\begin{array}{c}0.0176 \\
(0.0096)\end{array}$ & $\begin{array}{l}-0.0023 \\
(0.0073)\end{array}$ & $\begin{array}{l}-0.0091 \\
(0.0094)\end{array}$ & $\begin{array}{c}0.0038 \\
(0.0064)\end{array}$ & $\begin{array}{c}0.0032 \\
(0.0045)\end{array}$ & $\begin{array}{l}-0.0015 \\
(0.0041)\end{array}$ & $\begin{array}{c}0.0121 \\
(0.0153)\end{array}$ \\
\hline TPI in Q4 & $\begin{array}{c}0.057 \\
(0.0104)\end{array}$ & $\begin{array}{l}0.0009 \\
(0.0069)\end{array}$ & $\begin{array}{l}-0.0323 \\
(0.0082)\end{array}$ & $\begin{array}{l}-0.0122 \\
(0.0059)\end{array}$ & $\begin{array}{l}0.0089 \\
(0.0055)\end{array}$ & $\begin{array}{l}-0.0044 \\
(0.0038)\end{array}$ & $\begin{array}{c}0.0248 \\
(0.0149)\end{array}$ \\
\hline Cert X TPI in Q4 & $\begin{array}{c}0.0344 \\
(0.0107)\end{array}$ & $\begin{array}{l}-0.0083 \\
(0.0070)\end{array}$ & $\begin{array}{l}-0.0087 \\
(0.0083)\end{array}$ & $\begin{array}{c}0.0051 \\
(0.0060)\end{array}$ & $\begin{array}{c}0.0163 \\
(0.0056)\end{array}$ & $\begin{array}{c}0.0009 \\
(0.0039)\end{array}$ & $\begin{array}{c}0.0363 \\
(0.0153)\end{array}$ \\
\hline Dec '17 Covariates & Yes & Yes & Yes & Yes & Yes & Yes & Yes \\
\hline Income Dummies & Yes & Yes & Yes & Yes & Yes & Yes & Yes \\
\hline SOA Dummies & Yes & Yes & Yes & Yes & Yes & Yes & Yes \\
\hline Status Dummies & Yes & Yes & Yes & Yes & Yes & Yes & Yes \\
\hline Observations & 180,989 & 180,989 & 180,989 & 180,989 & 180,989 & 180,989 & 180,989 \\
\hline Adjusted $\mathrm{R}^{2}$ & 0.066 & 0.014 & 0.020 & 0.006 & 0.024 & 0.017 & 0.082 \\
\hline Mean dep. var. & 0.1090 & 0.0410 & 0.0530 & 0.0240 & 0.0220 & 0.0100 & 0.2410 \\
\hline
\end{tabular}

Notes: heteroskedasticity-robust standard errors in parentheses. ${ }^{*} \mathrm{p}<0.1 ;{ }^{*} \mathrm{p}<0.05 ; * * * \mathrm{p}<0.01$. 
Figure 13: RCT IV analysis, coefficient estimates for TPI quartile interactions

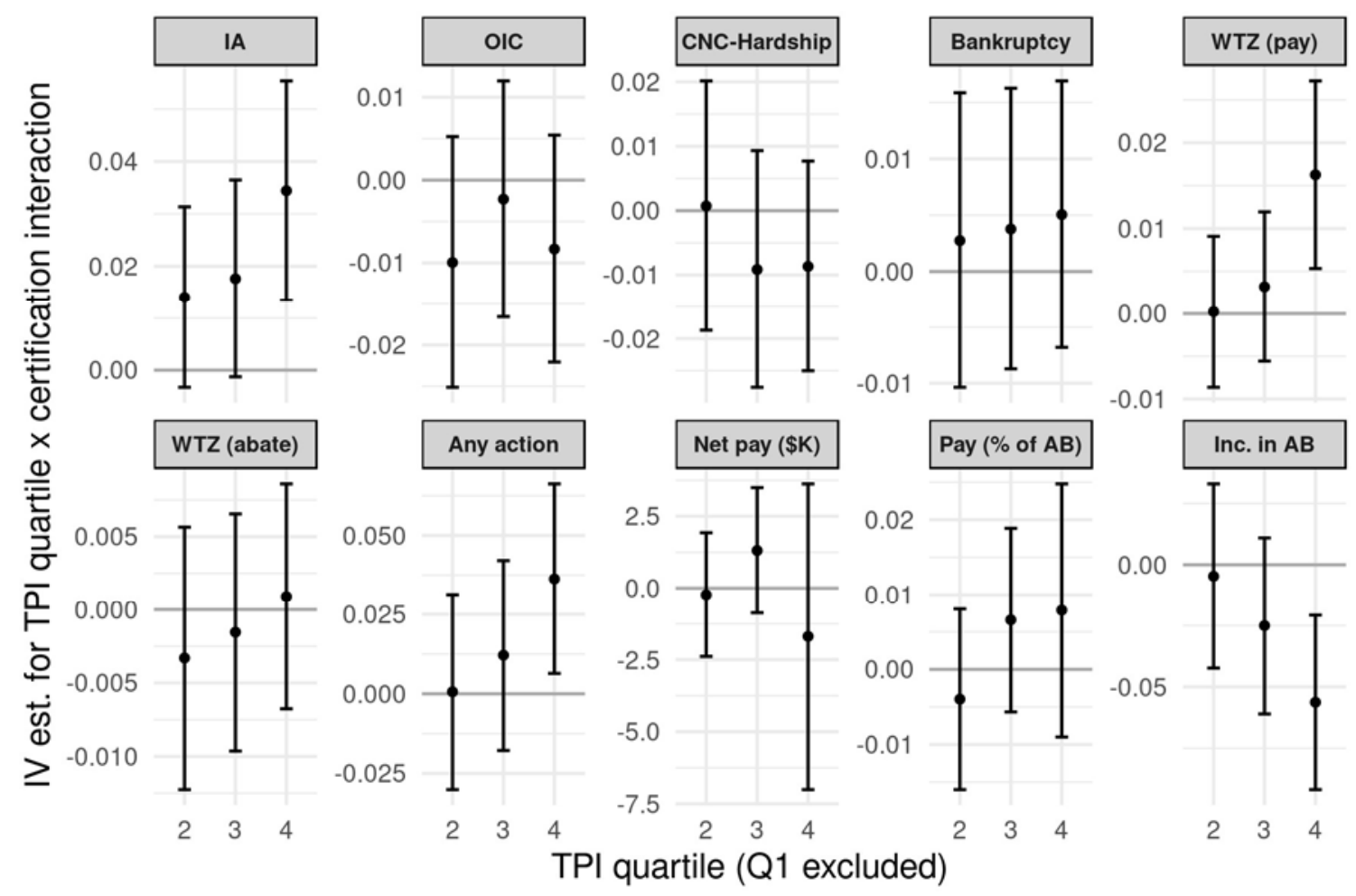

Notes: This figure plots the estimated treatment interaction coefficients and $95 \%$ confidence intervals, for TPI quartiles 2, 3, and 4 (quartile 1 is excluded), for ten separate outcomes.

\section{Indirect effects of the passport program}

In this section, we study whether the passport program has a deterrent effect, resulting in faster or more complete resolution by taxpayers who have not been certified for passport denial or revocation, but who seek to avoid certification. This differs from our study in the previous section, in which we studied the direct effect once a taxpayer was certified. Note that this population is vastly larger than the population of taxpayers who have been certified.

\subsection{Indirect effect related to statutory threshold}

To understand the indirect effects on initially ineligible taxpayers (those with debt below the thresholds), we will take advantage of the eligibility threshold. The hypothesis is that, after the introduction of the passport revocation policy, the cost of having tax debt above the eligibility threshold increased, and thus those with tax debt below the threshold have an additional incentive to remain below that threshold. (Recall there is no reason to observe exceptional bunching from above, as one cannot reduce one's debt to just below the threshold to get 
decertified.) We test for this effect by looking to see if taxpayers "bunch" below the (changing) threshold.

Figure 14 presents histograms of total assessed balance in December of each year 2010 through 2019 , grouping by taxpayers in each $\$ 1,000$ balance bucket. Although there is indeed evidence of bunching below $\$ 50,000$, this pattern starts well before the passport program was passed into law in 2015, and certainly before its rollout and implementation after that. It is also notable that the bunching below $\$ 50,000$ persists even when the passport threshold begins rising. Our hypothesis is that the observed bunching is driven not directly by the passport program, but instead is related to the streamlined Installment Agreements and other Installment Agreement policies that use a $\$ 50,000$ threshold. If the potential certification for passports makes payment plans more attractive, this could increase the bunching below $\$ 50,000$.

Figure 14: Histogram of taxpayers by total assessed balance

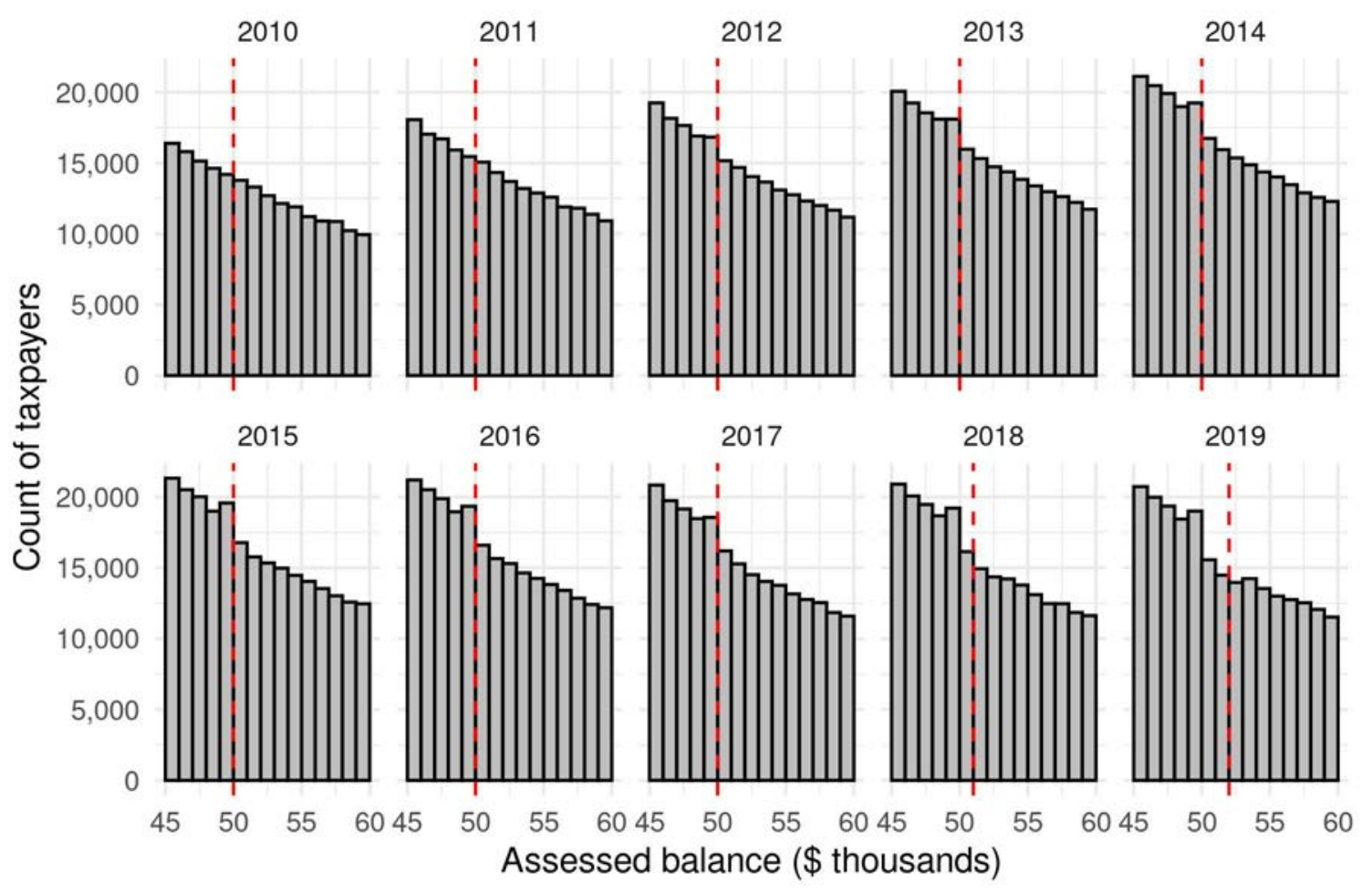

Notes: This figure plots the count of taxpayers in each $\$ 1,000$ bucket by total assessed balance, in December of each year. The red lines depict the passport threshold: $\$ 50,000$ in every year until rising to $\$ 51,000$ in 2018 , and $\$ 52,000$ in 2019.

\subsection{Indirect effect related to other enforcement tools}


Another potential mechanism by which the passport program could have an indirect effect on taxpayer compliance is by increasing the efficacy of other existing enforcement tools, especially liens and levies. In addition to having a debt balance above the statutory threshold, a prerequisite for passport certification is that a taxpayer either has had a Notice of Federal Tax Lien filed and the associated Collection Due Process (CDP) hearing rights have expired, or a Notice of Levy has been issued. Each of these tools (liens and levies) has its own effect on taxpayer compliance (see, e.g., Turk et al. (2016) and Collins et al. (2018)). We hypothesize that with the passport program in place, these tools may be even more effective, especially so for taxpayers with balance above the passport program's statutory threshold. For such a taxpayer, the imposition of a new lien or levy would also carry the cost associated with the potential for imminent passport certification, and thus might induce a stronger response than a lien or levy imposed prior to the passport program.

Credible identification of these more subtle indirect effects of the passport program would require overcoming significant statistical challenges, including the endogeneity of liens and levies and disentangling the various other policy and enforcement changes that occurred in the years around the announcement and implementation of the passport program. For this study, we note the issue and suggest it as a promising avenue for future research.

\section{Policy implications}

What does our empirical analysis imply about the revenue and welfare implications of the passport program? To answer this question, we consider the estimates we have produced of the behavioral response of those denied passport-related requests and the effect of being certified for passport revocation. The results from our heterogeneity analyses above suggest that there are important differences between the pre-existing stock of eligible taxpayers and the taxpayers that became newly eligible once the program was rolled out. We thus provide separate estimates for these two groups.

The State Denied analysis relies on a comparison of those certified taxpayers who were denied some request by the State Department to a control group of randomly-selected certified taxpayers. By comparing their behavior in the months following the passport request denial, we learn about the incremental effect of denial, above and beyond the base level of activity for certified taxpayers over the same time. In Section 5.1, we concluded that for the average 
passport-denied taxpayer, denial led to additional payments of about $\$ 9,000$ over the twelve months following denial. This $\$ 9,000$ estimate reflects a mix of new and pre-existing cases. When we do the same analysis separately for these groups, we find that the effect on new cases is stronger than for pre-existing cases. Denied requests lead to average additional payments of $\$ 12,600$ for new cases, and $\$ 7,300$ for pre-existing cases.

In Section 5.2, we investigated the behavioral effect of certification, which applies to a much larger population. We concluded that, as expected, the per-taxpayer effects were smaller than those in the State Denied analysis, but in many cases still statistically significant and non-trivial. We estimate a marginally significant effect on payments as a share of starting balance of $0.34 \%$ of the starting balance (a $4.3 \%$ increase in the payoff rate from a mean of $7.8 \%$ ). Recall that our main specification excluded taxpayers with a balance above \$1 million; when we include all taxpayers, the estimate is slightly lower at $0.33 \%$. Applied to the average starting balance of about $\$ 195,000$, this implies that certification causes an additional $\$ 644$ in payments, over two years. Again, this reflects a mix of new and pre-existing cases. Estimated separately, we find larger effects among new cases: $0.57 \%$ for new versus $0.11 \%$ for pre-existing. Applied to their average starting balances, this implies an additional $\$ 1,112$ and $\$ 222$ in payments, for new and pre-existing cases, respectively.

Table 9 summarizes these estimated effects. The separate estimates for pre-existing and new cases are useful in evaluating the passport program. The pre-existing cases represent a one-time boost in revenue; these cases would have been certified earlier had the program been in place all along, but in fact were all certified in a short period of time when the program was rolled out. The new cases better represent the ongoing effect of the program; these cases become newly eligible over time, and so offer a better measure of how the program may affect collections going forward. Note also that these estimates likely undercount the total effect, because some of the response to certification or denial includes taxpayers initiating Installment Agreements, whose effect on payments would be realized over a longer period. Finally, keep in mind that some of the impacts of the program may result in new payments but are still productive outcomes for tax administration, such as new CNC designations and new abatements. 
Table 9: Marginal revenue estimates

\begin{tabular}{llrr}
\hline \hline & & Pre-existing cases & New cases \\
\hline Effect of denied requests & & \\
Estimated payment effect & $\$ /$ person & $\$ 7,300$ & $\$ 12,600$ \\
\hline Effect of certification & & & \\
Coefficient estimate & $\%$ of balance & $0.11 \%$ & $0.57 \%$ \\
Average total balance & $\$$ & $\$ 202,000$ & $\$ 195,000$ \\
Estimated payment effect & $\$ /$ person & $\$ 222$ & $\$ 1,112$ \\
\hline \hline
\end{tabular}

Notes: This table reports the marginal revenue estimates, separately for pre-existing and new cases. See Section 5.1 for further detail on the effect of denied requests, and Sections 5.2 and 5.3 for the effect of certification.

As has been noted by Slemrod and Yitzhaki (1987) and Keen and Slemrod (2017), that the program raises revenue is not dispositive as to whether it had a positive welfare impact. A welfare analysis must consider that the additional money raised is not a resource gain but is rather a transfer from private citizens (albeit those with tax debt) to the government, which has social value (only) to the extent that the social value of the government services it enables exceeds the social value of the foregone taxpayer income; in addition, a welfare analysis should consider not just the additional dollars collected, but also the administrative cost of the program and the private costs induced by it. For a monetary sanction, the private costs are predominantly compliance costs, but in the case of a collateral sanction they also include the utility loss of those whose passport is denied. The marginal administrative costs should be net of any resource cost saving due to running a somewhat less extensive passport program due to the tax-related certifications and revocations.

The program passes the welfare test if the following condition holds (where $\phi$ is the marginal social value of public spending, assumed to be greater than one):

$$
\phi(\Delta \text { Revenue }-\Delta \text { Administrative Cost })-\Delta \text { Private Cost }>0
$$

As noted above, we estimate that for new cases, certification leads to an additional $\$ 1,112$ in payments and denial to an additional $\$ 12,600$ in payments. We observe that $3-4 \%$ of certified 
taxpayers subsequently had requests denied by the State Department, so that the total effect can be approximated as $\$ 1,112+\$ 12,600^{*} 0.035=\$ 1,553 .{ }^{23}$ For the IRS-related administrative costs, after an initial fixed cost of setting up the program, the marginal cost of an additional certification includes the time of IRS and State Department staff in processing the certification, and the cost of mailing letters from the IRS and State Department; based on internal IRS estimates, we assume these together amount to $\$ 25$ per certified taxpayer. Then, so long as the private cost of certification is less than $\phi(\$ 1,553-\$ 25)$, we can conclude that the passport program is welfare-improving within this framework. ${ }^{24}$ As noted above, the private cost of collateral sanctions should include the foregone utility from restricted travel options due to passport denial.

This calculation does not incorporate any saving in administrative costs due to the fact that more labor-intensive enforcement policies do not have to be applied, so that the welfare gain of the certification program may be understated. It also ignores the fact that, in principle, collateral sanctions could lower the cost of providing the service to which they restrict access. In this setting, for example, by restricting access to passports the program may make it less costly for the State Department to produce and monitor passports because fewer individuals request them. This effect could offset some of the administrative cost of administering the collateral sanctions, and if large enough could in principle result in net negative administrative costs. It also ignores the private utility costs of foregoing a passport and the benefits that having a passport provides.

\section{Conclusions}

This paper provides the first evidence on the effects of a large-scale collateral sanction program, studying the introduction and first two years of operation of the IRS' passport certification and revocation program. By observing the behavior of a subset of seriously delinquent taxpayers who were denied passport requests, and leveraging a randomized control trial-style implementation of the program rollout, we provide evidence that the passport program leads a substantial number of

\footnotetext{
${ }^{23}$ The effects of denial and certification are distinct and so can be added without resulting in double counting. Our denial estimates rely on a control group of certified taxpayers, so that the estimated effects are above and beyond any certification effect. In addition, those taxpayers who are denied requests by the State Department must not have responded to certification itself, or else they would have been decertified and no longer subject to denial. This interpretation is confirmed by a robustness check of our certification regression analysis that excludes the State Denied taxpayers, and finds consistent results (see Appendix, Figure 17).

24 The corresponding test using the estimates for the pre-existing cases would be that $\phi(\$ 465-\$ 25)$ exceeds the private cost of certification for the pre-existing case taxpayers.
} 
taxpayers to take compliance actions they otherwise would not have. Our work suggests that tax agencies (and legislatures) can consider collateral sanctions as a viable option for improving tax compliance. 


\section{References}

Allingham, Michael G. and Agnar Sandmo. 1972. "Income Tax Evasion: A Theoretical Analysis." Journal of Public Economics 1: 323-338.

Angaretis, Chad, Brian Galle, Paul R. Organ, and Allen Prohofsky. 2021. "Does Shaming Pay?

Evaluating California's Top 500 Tax Delinquent Publication Program.” Working paper.

Angrist, Joshua. 2005. "Instrumental Variables in Experimental Criminological Research: What, Why, and How?" NBER Technical Working Paper 314.

Beers, Tom, Carol Hatch, Joe Saldana, and Jeff Wilson. 2015. "IRS Collectibility Curve." Taxpayer Advocate Service Research, Internal Revenue Service.

Blank, Joshua D. 2013. "Collateral Compliance." U. Pa. L. Rev. 162 (2013): 719.

Collins, Brett, Alan Plumley, Ishani Roy, Alex Turk, Terry Ashley, and Jeff Wilson. 2018. "The Effectiveness of the Notice of Federal Tax Lien and Alternative IRS Letters in Resolving Individual Tax Debt." IRS Bulletin.

Florida, Richard. 2011. “America’s Great Passport Divide.” The Atlantic, March 15, 2011. Gonçalves, Pedro. "IRS to Revoke 260,000 American Passports." International Investment, October 16, 2018.

https://www.internationalinvestment.net/internationalinvestment/news/3505803/irs-revoke-260american-passports.

Internal Revenue Service (IRS). 2018. "IRS Urges Travelers Requiring Passports to Pay Their Back Taxes or Enter into Payment Agreements; People Owing \$51,000 or More Covered." January 18, 2018. Accessed at https://www.irs.gov/newsroom/irs-urges-travelers-requiringpassports-to-pay-their-back-taxes-or-enter-into-payment-agreements-people-owing-51000-ormore-covered.

Keen, Michael and Joel Slemrod. 2017. "Optimal Tax Administration." Journal of Public Economic 152: 133-142.

Kenchington, David and Roger White. 2021. "Income Tax Noncompliance and Professional License Suspension: Evidence from Missouri." Working paper.

Kuchumova, Yulia. 2018. "A Collateral Tax Sanction: When Does it Mimic a Welfare-Improving Tag?” International Tax and Public Finance 25(4): 841-866.

Kuchumova, Yulia. 2021. “Tax Debt Collection: When Does Suspension of a Driver's License Help?" Working paper. 
Phillips Erb, Kelly. 2017. "If You Owe Taxes, You Could Lose Your Passport And Your Ability To Fly.” Forbes, January 26, 2017. https://www.forbes.com/sites/kellyphillipserb/2017/01/26/ifyou-owe-taxes-to-irs-you-could-lose-your-passport-and-your-right-to-fly/?sh=2dcbc03f69bc.

Polinsky, A. Mitchell and Steven Shavell. 2000. "The Economic Theory of Public Enforcement of Law." Journal of Economic Literature 38(1): 45-76.

Slemrod, Joel. 2019. “Tax Compliance and Enforcement.” Journal of Economic Literature 57(4): 904-954.

Slemrod, Joel and Shlomo Yitzhaki. 1987. "The Optimal Size of a Tax Collection Agency." Scandinavian Journal of Economics 89(2), 183-192.

Treasury Inspector General for Tax Administration (TIGTA). 2019. Implementation of the Passport Provisions of the FAST Act Was Generally Successful, and the Internal Revenue Service Is Working on Objective Criteria for Passport Revocations, September 19, 2019. Reference Number: 2019-30-068.

Turk, Alex, John Iuranich, Stacy Orlett, and Saurabh Datta. 2016. "Resolving Unpaid Taxes and the Notice of Federal Tax Lien: Evidence from the Fresh Start Initiative." IRS Bulletin.

U.S. Govt. Accountability Office. 2011. Federal Tax Collection. Potential for Using Passport Issuance to Increase Collection of Unpaid Taxes. GAO-11-272.

U.S. House. 2015. Conference Report on H.R. 22, Surface Transportation Reauthorization and Reform Act of 2015. https://www.congress.gov/congressional-record/2015/12/01/housesection/article/H8679-2.

Urist, Jacoba. 2012. "No Taxes, No Travel: Why the IRS Wants the Right to Seize Your Passport." The Atlantic, April 17. 


\section{Appendix}

Table 10: Summary statistics for first-time certified taxpayers

\begin{tabular}{|c|c|c|c|c|c|c|}
\hline & Mean & St Dev & 25th Pctile & Median & 75th Pctile & \# Obs \\
\hline \multicolumn{7}{|l|}{ Certified balance } \\
\hline Assessed balance, penalties, and interest ( $\$$ thousands) & $\$ 197$ & $\$ 1,146$ & $\$ 68$ & $\$ 98$ & $\$ 172$ & 394,000 \\
\hline Number of modules & 5 & 4 & 2 & 4 & 7 & 394,000 \\
\hline Age of oldest module (years) & 7 & 3 & 4 & 7 & 9 & 394,000 \\
\hline \multicolumn{7}{|l|}{ Most recent tax filing prior to certification } \\
\hline Total positive income (\$ thousands) & $\$ 149$ & $\$ 5,551$ & $\$ 30$ & $\$ 68$ & $\$ 134$ & 293,000 \\
\hline Adjusted gross income ( $\$$ thousands) & $\$ 103$ & $\$ 1,926$ & $\$ 24$ & $\$ 60$ & $\$ 120$ & 293,000 \\
\hline \multicolumn{7}{|l|}{ Primary income source } \\
\hline Wages & 0.18 & 0.39 & 0.00 & 0.00 & 0.00 & 394,000 \\
\hline Schedule C income & 0.28 & 0.45 & 0.00 & 0.00 & 1.00 & 394,000 \\
\hline Interest, dividends, and capital gains & 0.25 & 0.44 & 0.00 & 0.00 & 1.00 & 394,000 \\
\hline Age in 2017 (years) & 53 & 11 & 46 & 53 & 61 & 379,000 \\
\hline
\end{tabular}

Notes: Values are rounded for disclosure purposes. Includes first-time certifications through April 2020, when certifications were paused due to COVID-19.

Figure 15: Observation counts by relative month for State Denied analysis

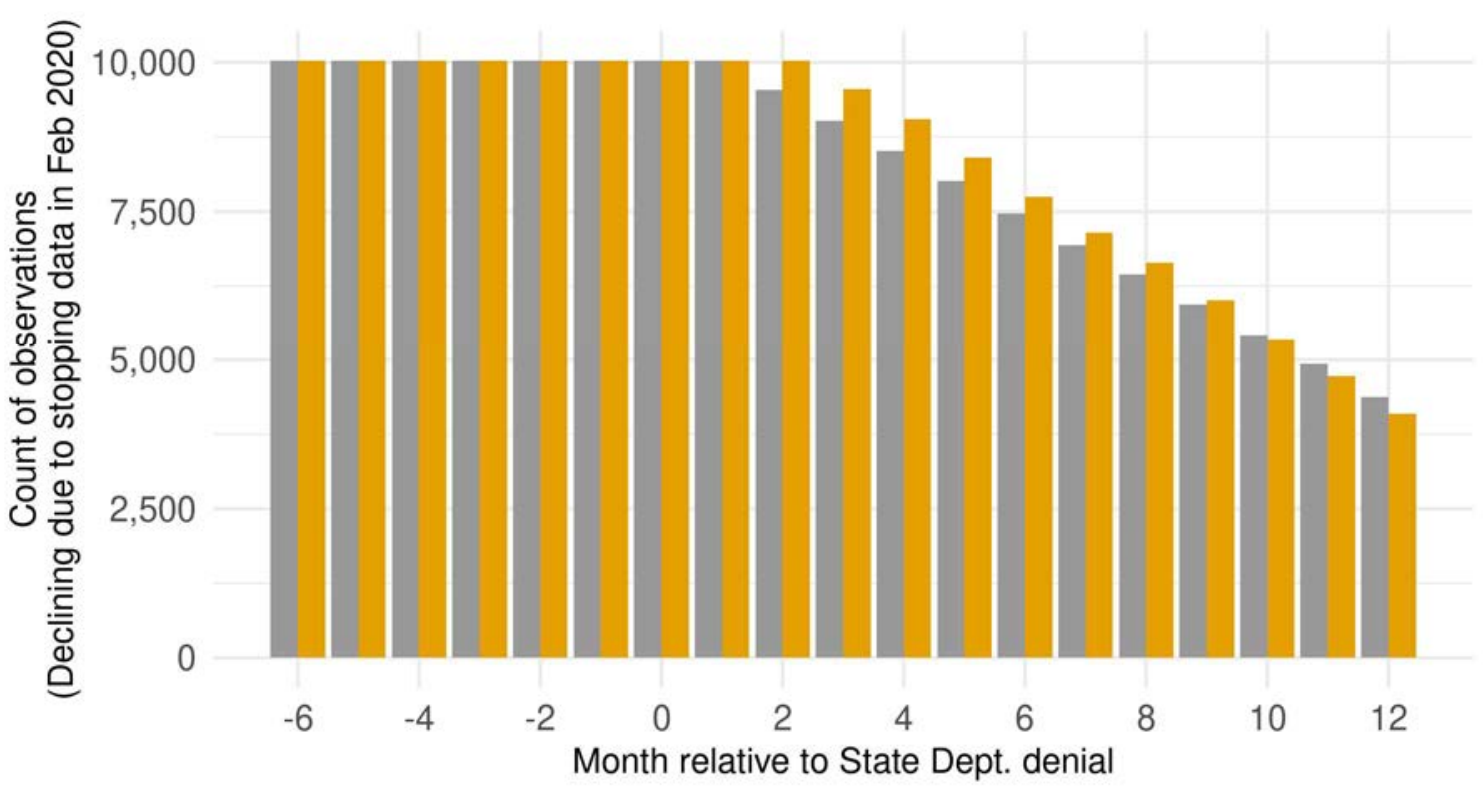

Data sample:

Random sample of those currently certified in $t=0$

Those denied action by State Dept. in $t=0$ 
Notes: We only include outcome observations through February 2020, to avoid any effect of Covid19. We include all denied passport requests through December 2019. This means that some taxpayers do not have a full twelve months of post-denial observations, and the size of the groups included for each relative month share calculation declines over time.

Figure 16: Share currently in certain statuses, State Denied vs. control group, split by income

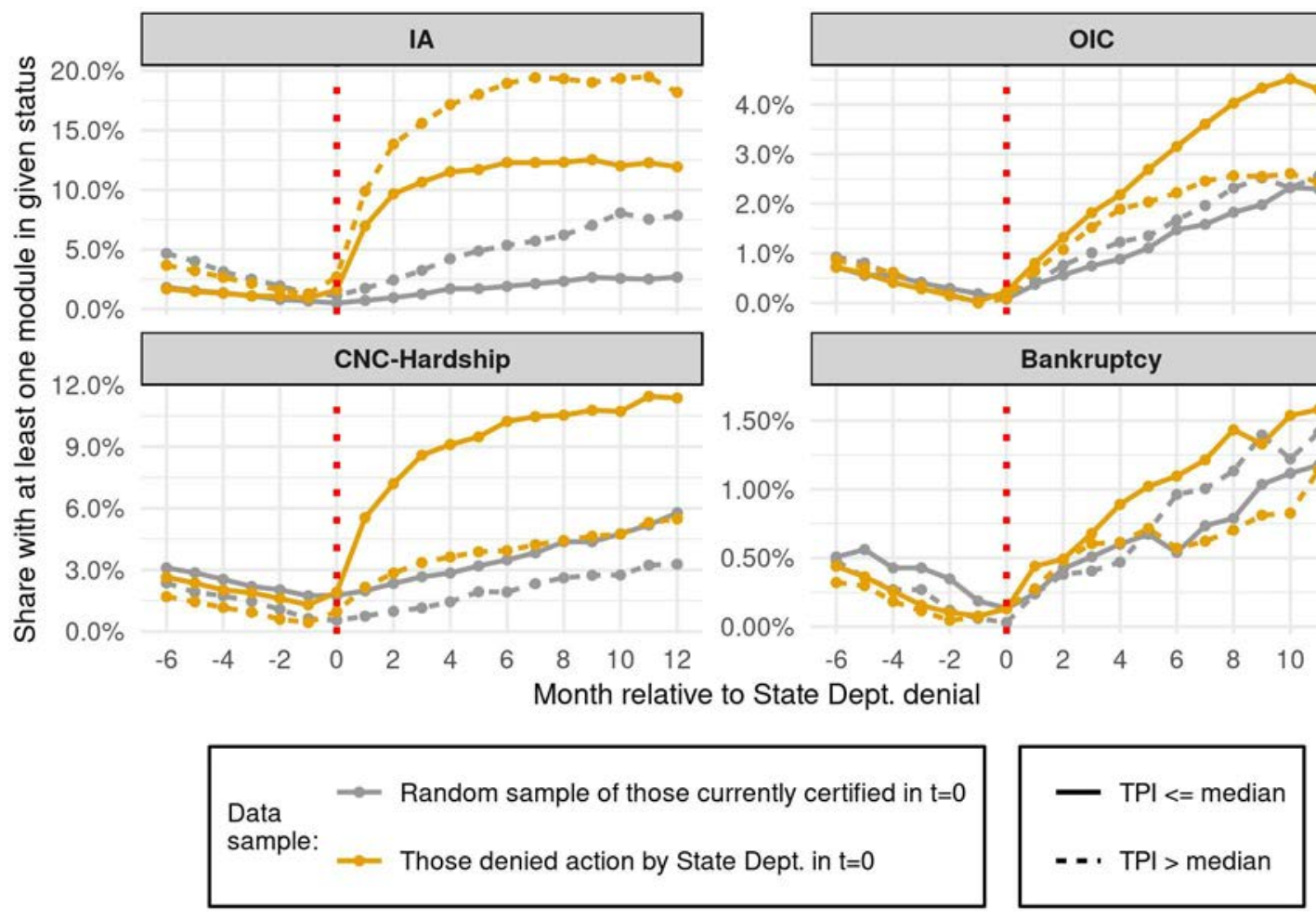

Notes: This figure presents the share of taxpayers in each group with at least one module in the given status. Taxpayers are split into the State Denied and control groups, and further into those with their most recent tax filing's total positive income above or below the median for the full set of taxpayers. Those without a recent tax filing are excluded. 
Table 11: RCT analysis, summary statistics for data used in main analysis

\begin{tabular}{|c|c|c|c|c|c|c|c|}
\hline Statistic & Mean & St. Dev. & Min & $\operatorname{Pctl}(25)$ & Median & $\operatorname{Pctl}(75)$ & Max \\
\hline Treatment SSN & 0.95 & 0.22 & 0 & 1 & 1 & 1 & 1 \\
\hline Certified & 0.96 & 0.20 & 0 & 1 & 1 & 1 & 1 \\
\hline \multicolumn{8}{|l|}{ Dec '17 Covariates } \\
\hline Assessed balance (\$K) & 145.107 & 138.206 & 0.005 & 66.815 & 95.217 & 162.005 & 999.599 \\
\hline Max module age (yrs) & 6.377 & 2.783 & 0.000 & 4.216 & 6.899 & 8.720 & 11.997 \\
\hline Share of assessed balance older than 9 years & 0.075 & 0.210 & 0.000 & 0.000 & 0.000 & 0.000 & 1.000 \\
\hline Indicator for presence of unfiled returns & 0.205 & 0.404 & 0.000 & 0.000 & 0.000 & 0.000 & 1.000 \\
\hline Number of annual modules & 3.944 & 2.440 & 0.000 & 2.000 & 4.000 & 6.000 & 10.000 \\
\hline Number of quarterly modules & 0.528 & 2.420 & 0.000 & 0.000 & 0.000 & 0.000 & 40.000 \\
\hline \multicolumn{8}{|l|}{ Balance outcomes (as of Dec '19) } \\
\hline Assessed balance $(\$ K)$ & 130.29 & 171.19 & 0.0 & 52.7 & 84.5 & 151.1 & $15,013.7$ \\
\hline Change in assessed balance (\$K) & -14.82 & 129.16 & -996.5 & -41.0 & 0.0 & 15.4 & $14,747.5$ \\
\hline Change in log assessed balance & -0.618 & 1.593 & -6.905 & -0.489 & 0.000 & 0.137 & 8.737 \\
\hline Fall in assessed balance & 0.457 & 0.498 & 0 & 0 & 0 & 1 & 1 \\
\hline Increase in assessed balance & 0.420 & 0.494 & 0 & 0 & 0 & 1 & 1 \\
\hline \multicolumn{8}{|l|}{ Cumulative payments (Dec '17 to Dec '19) } \\
\hline Made payment & 0.477 & 0.499 & 0 & 0 & 0 & 1 & 1 \\
\hline Net payment $(\$ K)$ & 12.128 & 55.241 & -957.0 & 0.0 & 0.0 & 4.6 & $7,151.5$ \\
\hline Payment as share of Dec '17 AB (\%) & 0.078 & 0.206 & 0 & 0 & 0 & 0 & 1 \\
\hline \multicolumn{8}{|c|}{ Decertification actions, ever taken over period from Mar '18 to Dec '19 } \\
\hline New IA & 0.076 & 0.265 & 0 & 0 & 0 & 0 & 1 \\
\hline New OIC & 0.028 & 0.166 & 0 & 0 & 0 & 0 & 1 \\
\hline New CNC & 0.040 & 0.195 & 0 & 0 & 0 & 0 & 1 \\
\hline New Bankruptcy & 0.017 & 0.130 & 0 & 0 & 0 & 0 & 1 \\
\hline Assessed balance to zero (by payment) & 0.016 & 0.125 & 0 & 0 & 0 & 0 & 1 \\
\hline Assessed balance to zero (by abatement) & 0.008 & 0.090 & 0 & 0 & 0 & 0 & 1 \\
\hline Assessed balance to zero (other) & 0.076 & 0.265 & 0 & 0 & 0 & 0 & 1 \\
\hline Any resolution action other than $A B$ zero (other) & 0.172 & 0.378 & 0 & 0 & 0 & 0 & 1 \\
\hline
\end{tabular}

Notes: all variables have 266,890 observations. Percentiles are rounded for disclosure purposes. 
Figure 17: RCT IV coefficient estimates using alternative data filters

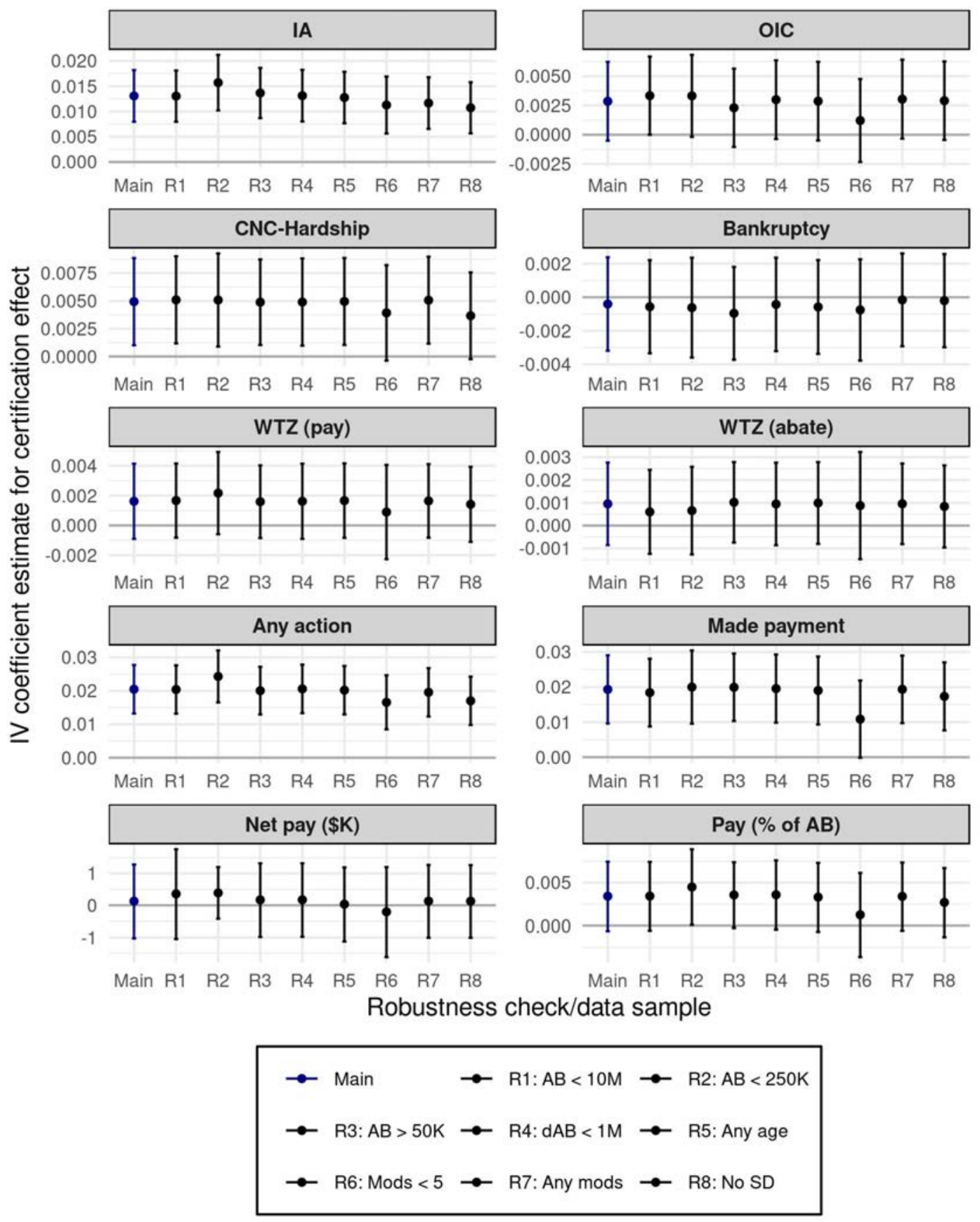

Notes: This figure presents the IV coefficient estimates, and $95 \%$ confidence intervals, when running the RCT IV analyses using alternative data filters. The main specification restricts to those with Dec ' 17 assessed balance $<\$ 1 \mathrm{M}$, with max module age $<12$ years, and number of annual modules $<10$ and quarterly modules $<40$. R1-R3 adjust on Dec '17 assessed balance, expanding up to $\$ 10 \mathrm{M}$, restricting to those $<\$ 250 \mathrm{~K}$, or restricting to those $>\$ 50 \mathrm{~K}$, respectively. R4 restricts on the observed change in assessed balance, excluding any with a change $>\$ 1 \mathrm{M}$. R5 removes the 
restriction on max module age. R6 and R7 adjust the module count restriction, with R6 restricting to those with $<5$ annual or $<20$ quarterly modules, and $\mathrm{R} 7$ removing the module count restriction. R8 removes taxpayers that have passport-related requests denied by the State Department, to confirm that the certification effects are not simply reflecting the effects of these denials.

Figure 18: RCT IV coefficient estimates using different end months

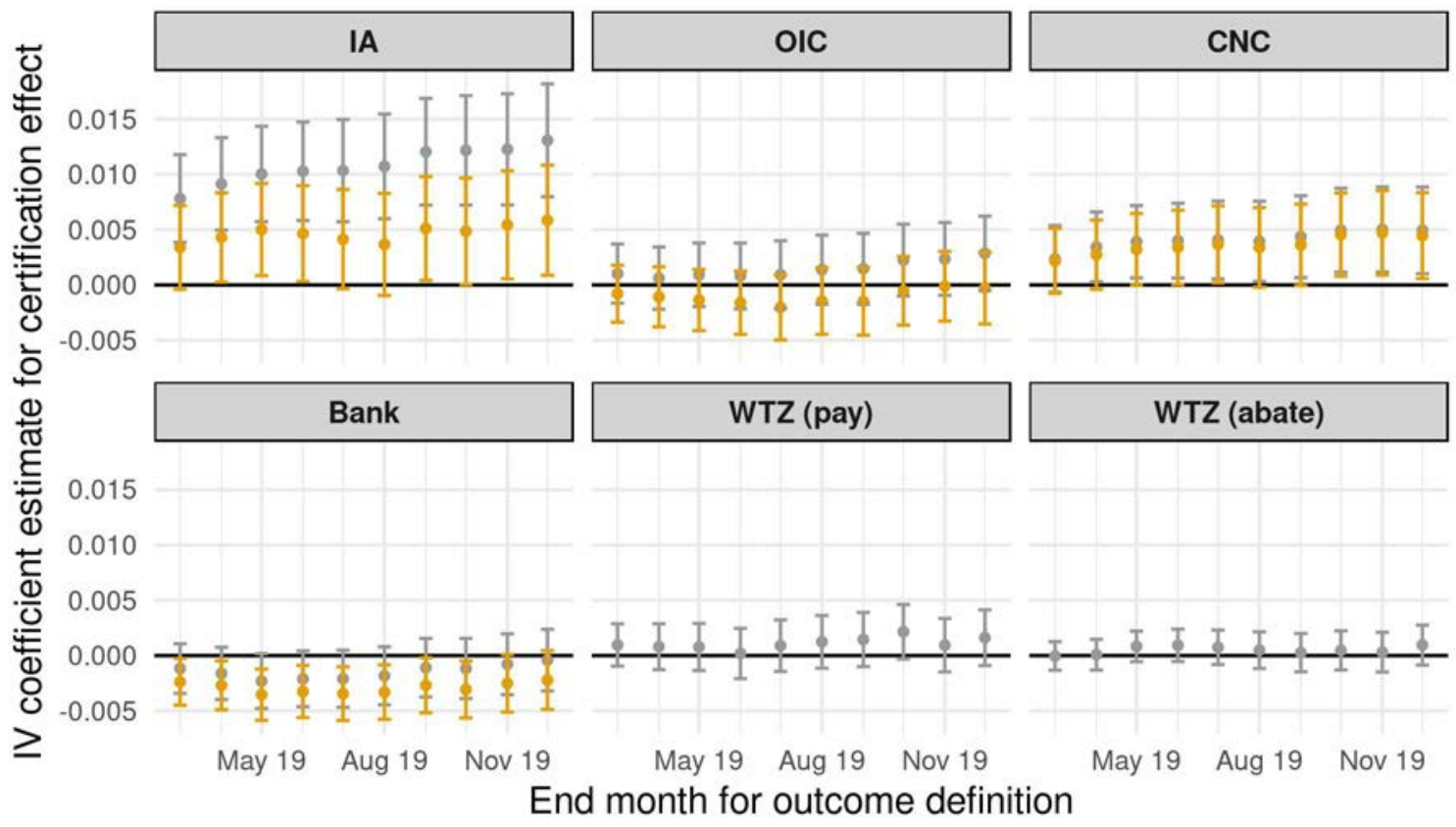

Outcome definition: $\rightarrow$ Took action $\rightarrow$ Took action and remained uncertified

Notes: This figure presents the IV coefficient estimates, and $95 \%$ confidence intervals, when running the RCT IV analyses using different end months. Our main specification uses December 2019 as the end month. 
Table 12: RCT IV analysis, results for taking actions and remaining uncertified

\begin{tabular}{|c|c|c|c|c|}
\hline & \multicolumn{4}{|c|}{ Taking new action and remaining uncertified as of Dec ' 19} \\
\hline & $\begin{array}{l}\mathrm{IA} \\
(1)\end{array}$ & $\begin{array}{l}\text { OIC } \\
(2)\end{array}$ & $\begin{array}{l}\text { CNC } \\
(3)\end{array}$ & $\begin{array}{c}\text { Bankruptcy } \\
\text { (4) }\end{array}$ \\
\hline Certified & $\begin{array}{l}0.0058 \\
(0.0025)\end{array}$ & $\begin{array}{l}-0.0003 \\
(0.0017)\end{array}$ & $\begin{array}{l}0.0045 \\
(0.0020)\end{array}$ & $\begin{array}{l}-0.0022 \\
(0.0014)\end{array}$ \\
\hline \multicolumn{5}{|c|}{ Covariates as of Dec '17: } \\
\hline $\begin{array}{l}\text { Assessed balance } \\
(\$ M)\end{array}$ & $\begin{array}{l}-0.0494 \\
(0.0033)\end{array}$ & $\begin{array}{c}0.016 \\
(0.0026)\end{array}$ & $\begin{array}{l}-0.0154 \\
(0.0030)\end{array}$ & $\begin{array}{l}0.0018 \\
(0.0018)\end{array}$ \\
\hline $\begin{array}{l}\text { Max module age } \\
\text { (yrs) }\end{array}$ & $\begin{array}{l}-0.0076 \\
(0.0002)\end{array}$ & $\begin{array}{l}-0.0018 \\
(0.0001)\end{array}$ & $\begin{array}{c}-0.00002 \\
(0.0002)\end{array}$ & $\begin{array}{l}-0.0005 \\
(0.0001)\end{array}$ \\
\hline $\begin{array}{l}\text { Share } A B>9 \text { yrs } \\
(\%)\end{array}$ & $\begin{array}{c}0.009 \\
(0.0020)\end{array}$ & $\begin{array}{l}-0.0078 \\
(0.0011)\end{array}$ & $\begin{array}{l}-0.0069 \\
(0.0018)\end{array}$ & $\begin{array}{l}-0.0011 \\
(0.0011)\end{array}$ \\
\hline $\begin{array}{l}\text { Unfiled returns } \\
(1 / 0)\end{array}$ & $\begin{array}{l}-0.0172 \\
(0.0009)\end{array}$ & $\begin{array}{l}-0.0066 \\
(0.0006)\end{array}$ & $\begin{array}{l}-0.006 \\
(0.0009)\end{array}$ & $\begin{array}{l}-0.003 \\
(0.0005)\end{array}$ \\
\hline $\begin{array}{l}\text { Modules } \\
\text { (\# of non-Form 941) }\end{array}$ & $\begin{array}{l}0.0034 \\
(0.0003)\end{array}$ & $\begin{array}{l}0.0027 \\
(0.0002)\end{array}$ & $\begin{array}{l}0.0014 \\
(0.0002)\end{array}$ & $\begin{array}{l}0.0006 \\
(0.0001)\end{array}$ \\
\hline $\begin{array}{l}\text { Modules } \\
\text { (\# of Form 941) }\end{array}$ & $\begin{array}{l}-0.0012 \\
(0.0002)\end{array}$ & $\begin{array}{l}0.0014 \\
(0.0002)\end{array}$ & $\begin{array}{l}0.0024 \\
(0.0002)\end{array}$ & $\begin{array}{l}0.0002 \\
(0.0001)\end{array}$ \\
\hline Constant & $\begin{array}{c}0.155 \\
(0.0034)\end{array}$ & $\begin{array}{l}0.0374 \\
(0.0022)\end{array}$ & $\begin{array}{l}0.0418 \\
(0.0026)\end{array}$ & $\begin{array}{l}0.0261 \\
(0.0017)\end{array}$ \\
\hline Income Dummies & Yes & Yes & Yes & Yes \\
\hline SOA Dummies & Yes & Yes & Yes & Yes \\
\hline Status Dummies & Yes & Yes & Yes & Yes \\
\hline Observations & 266,890 & 266,890 & 266,890 & 266,890 \\
\hline Adjusted $\mathrm{R}^{2}$ & 0.065 & 0.017 & 0.019 & 0.009 \\
\hline Mean dep. var. & 0.066 & 0.024 & 0.039 & 0.014 \\
\hline
\end{tabular}

Notes: heteroskedasticity-robust standard errors in parentheses. 
Table 13: RCT IV analysis, testing explanation for increase in $A B$ result

\begin{tabular}{|c|c|c|c|c|}
\hline \multirow[b]{2}{*}{$\begin{array}{r}\text { New IA/OIC/CNC: } \\
\text { New modules for } \\
\text { tax year: }\end{array}$} & \multicolumn{4}{|c|}{ Combination outcomes: Take action and add modules } \\
\hline & $\begin{array}{c}\text { Yes } \\
<=2016 \\
\text { (1) }\end{array}$ & $\begin{array}{c}\text { No } \\
<=2016 \\
\text { (2) }\end{array}$ & $\begin{array}{c}\text { Yes } \\
>=2017 \\
\text { (3) }\end{array}$ & $\begin{array}{c}\text { No } \\
>= \\
2017 \\
(4)\end{array}$ \\
\hline Certified & $\begin{array}{l}\mathbf{0 . 0 0 5 6} \\
(0.0020)\end{array}$ & $\begin{array}{l}-0.0034 \\
(0.0034)\end{array}$ & $\begin{array}{l}0.0104 \\
(0.0027)\end{array}$ & $\begin{array}{l}-0.0047 \\
(0.0039)\end{array}$ \\
\hline \multicolumn{5}{|c|}{ Covariates as of Dec '17: } \\
\hline $\begin{array}{l}\text { Assessed balance } \\
\text { (\$M) }\end{array}$ & $\begin{array}{l}-0.0187 \\
(0.0030)\end{array}$ & $\begin{array}{l}0.0447 \\
(0.0049)\end{array}$ & $\begin{array}{l}-0.0268 \\
(0.0039)\end{array}$ & $\begin{array}{l}0.0447 \\
(0.0053)\end{array}$ \\
\hline $\begin{array}{l}\text { Max module age } \\
\text { (yrs) }\end{array}$ & $\begin{array}{l}-0.0026 \\
(0.0002)\end{array}$ & $\begin{array}{l}-0.0129 \\
(0.0003)\end{array}$ & $\begin{array}{l}-0.0086 \\
(0.0002)\end{array}$ & $\begin{array}{l}-0.0139 \\
(0.0003)\end{array}$ \\
\hline $\begin{array}{l}\text { Share } A B>9 \text { yrs } \\
(\%)\end{array}$ & $\begin{array}{l}-0.0071 \\
(0.0015)\end{array}$ & $\begin{array}{l}0.0106 \\
(0.0027)\end{array}$ & $\begin{array}{l}-0.0051 \\
(0.0020)\end{array}$ & $\begin{array}{l}0.0107 \\
(0.0032)\end{array}$ \\
\hline $\begin{array}{l}\text { Unfiled returns } \\
(1 / 0)\end{array}$ & $\begin{array}{l}0.0173 \\
(0.0011)\end{array}$ & $\begin{array}{l}0.0407 \\
(0.0018)\end{array}$ & $\begin{array}{l}-0.0131 \\
(0.0010)\end{array}$ & $\begin{array}{l}-0.0293 \\
(0.0016)\end{array}$ \\
\hline $\begin{array}{l}\text { Modules } \\
\text { (\# of non-Form } 941\end{array}$ & $\begin{array}{l}0.0008 \\
(0.0002)\end{array}$ & $\begin{array}{l}0.0076 \\
(0.0004)\end{array}$ & $\begin{array}{c}0.011 \\
(0.0003)\end{array}$ & $\begin{array}{l}0.0225 \\
(0.0004)\end{array}$ \\
\hline $\begin{array}{l}\text { Modules } \\
\text { (\# of Form 941) }\end{array}$ & $\begin{array}{l}0.0018 \\
(0.0002)\end{array}$ & $\begin{array}{l}0.0031 \\
(0.0003)\end{array}$ & $\begin{array}{l}0.0001 \\
(0.0002)\end{array}$ & $\begin{array}{l}0.0032 \\
(0.0004)\end{array}$ \\
\hline Constant & $\begin{array}{l}0.0421 \\
(0.0026)\end{array}$ & $\begin{array}{l}0.1117 \\
(0.0043)\end{array}$ & $\begin{array}{l}0.1424 \\
(0.0036)\end{array}$ & $\begin{array}{l}0.1872 \\
(0.0050)\end{array}$ \\
\hline Income Dummies & Yes & Yes & Yes & Yes \\
\hline SOA Dummies & Yes & Yes & Yes & Yes \\
\hline Status Dummies & Yes & Yes & Yes & Yes \\
\hline $\begin{array}{l}\text { Observations } \\
\text { Adjusted } \mathrm{R}^{2}\end{array}$ & $\begin{array}{c}266,890 \\
0.020\end{array}$ & $\begin{array}{c}266,890 \\
0.020\end{array}$ & $\begin{array}{c}266,890 \\
0.083\end{array}$ & $\begin{array}{c}266,890 \\
0.123\end{array}$ \\
\hline Mean dep. var. & 0.04 & 0.1100 & 0.08 & 0.1770 \\
\hline
\end{tabular}

Notes: heteroskedasticity-robust standard errors in parentheses. The results suggest that the addition of new modules is driven by those taking new compliance actions (IA, OIC, and CNC), and that this helps explain why certification makes it more likely for a taxpayer to have an increase in assessed balance, on average. 
Figure 19: RCT IV analysis, coefficient estimates for TPI decile interactions

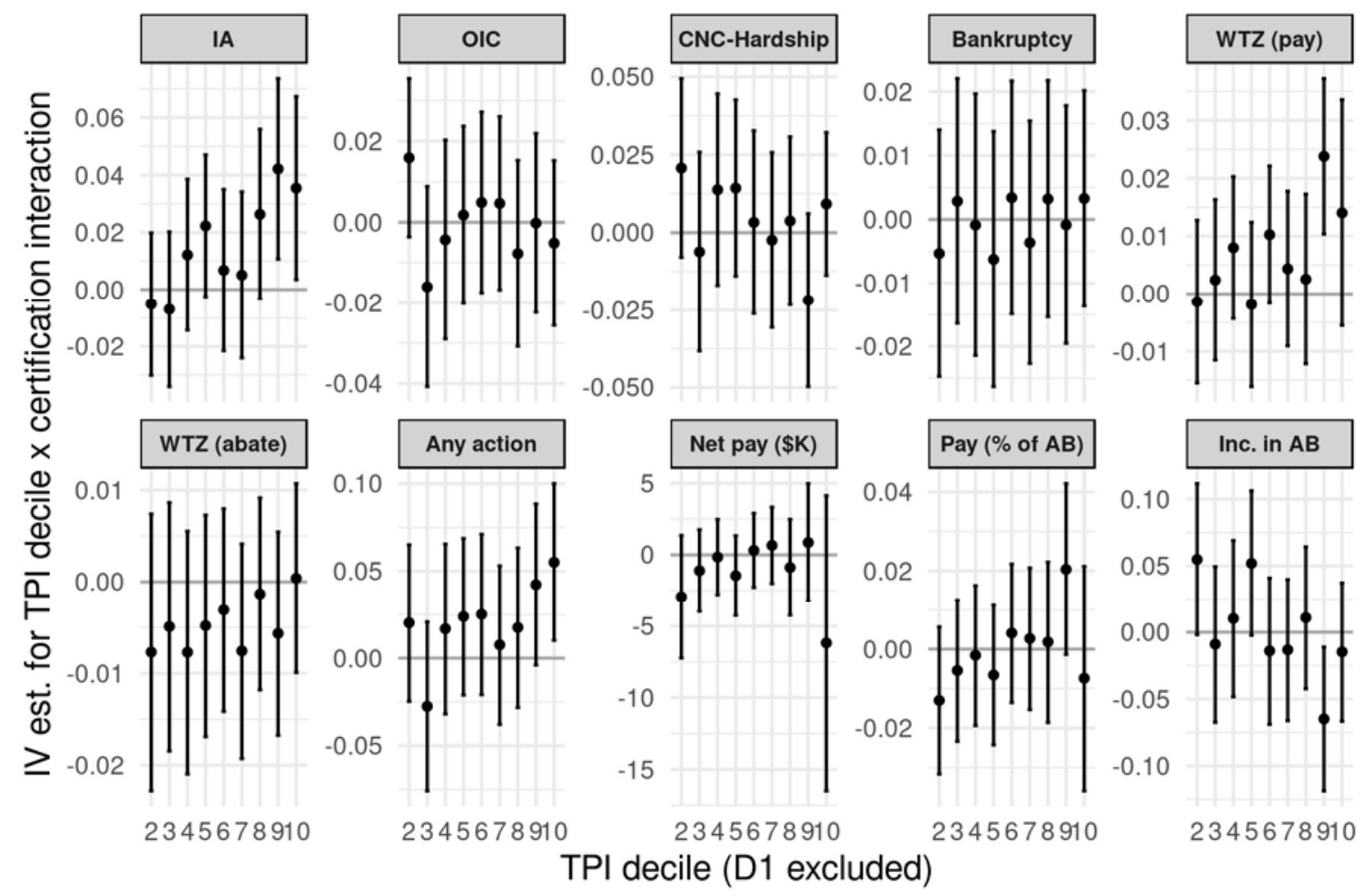

Notes: This figure plots the estimated treatment interaction coefficients and $95 \%$ confidence intervals, for TPI deciles 2 through 10 (decile 1 is excluded), for ten separate outcomes. 